\title{
Surface Velar Palatalization in Polish
}

\author{
Jerzy Rubach ${ }^{1,2}$
}

Received: 2 January 2017 / Accepted: 19 June 2018 / Published online: 22 October 2018

(C) The Author(s) 2018

\begin{abstract}
This article investigates a palatalization process called Surface Velar Palatalization that turns $/ \mathrm{kg} /$ into $\left[\mathrm{k}^{\mathrm{j}} \mathrm{g}^{\mathrm{j}}\right]$ before the front vowel $e$. What would appear to be a trivial rule, $k g \rightarrow k^{j} g^{j} / — \varepsilon$, turns out to be a highly complex process. The complexity is caused by several independent factors. First, Surface Velar Palatalization, $k g \rightarrow k^{j} g^{j}$, competes with Phonemic Velar Palatalization, $k g$ $\rightarrow t f$. Second, some but not all changes are restricted to derived environments. Third, some suffixes appear to be exceptions to one type of Palatalization but not to the other type. Fourth, /x/ behaves in an ambivalent way by undergoing one but not the other type of Palatalization. Fifth, Palatalization constraints interacting with segment inventory constraints yield different results in virtually the same contexts.

I argue that the complexity of Surface Velar Palatalization motivates derivational levels in Optimality Theory. Further, the condition of derived environments is expressed as a constraint that is ranked differently at different levels of evaluation.

A historical analysis of Surface Velar Palatalization tells the story of how the process came into being and operated for centuries in an unrestricted way. It subsequently became restricted to derived environments, which led to pronunciation reversals of the historical Duke of York type: $g \varepsilon \rightarrow g^{j} \varepsilon \rightarrow g \varepsilon$.*
\end{abstract}

Keywords Polish phonology · Derivational Optimality Theory · Velar palatalization $\cdot$ Derived environments $\cdot$ Pronunciation reversals

\section{J. Rubach}

jerzy.rubach@uw.edu.pl

1 University of Warsaw, Warsaw, Poland

2 University of Iowa, Iowa City, IA, USA 
This article investigates a palatalization process in Polish called Surface Velar Palatalization, ${ }^{1}$ which turns $/ \mathrm{k} \mathrm{g} /$ into $\left[\mathrm{k}^{\mathrm{j}} \mathrm{g}^{\mathrm{j}}\right]$ before the front vowel $e$. Aside from some cursory remarks in Gussmann (1980) and Rubach (1984), Surface Velar Palatalization has not been discussed in the generative literature to date, so the material is new. ${ }^{2}$ What would appear to be a trivial rule, $k g \rightarrow k^{j} g^{j} /-\varepsilon$, turns out to be a highly complex but fully regular process. Accounting for Surface Velar Palatalization is therefore a challenge and a test of adequacy for phonological theory.

On the theoretical side, this paper is a contribution to Stratal Optimality Theory (Stratal OT, henceforth) in two ways. First, it provides a new argument for the distinction of levels or strata stemming from the hitherto unexplored role played by segment inventories. Second, it investigates derived environments in Palatalization and postulates that they are best captured as an OT constraint that can be ranked differently at different levels of derivation. Third, a historical study of Surface Velar Palatalization contributes to an understanding of the life cycle of a process that Stratal OT is designed to model.

Arguments for Stratal OT have typically been based on opacity (Kiparsky 2000; Bermúdez-Otero 1999; Rubach 2000a). The weak point of such arguments is that Standard Optimality Theory (Prince and Smolensky 2004; McCarthy and Prince 1995) has developed a number of auxiliary theories that can handle opacity, including Output-Output Theory (Benua 1997), Sympathy Theory (McCarthy 1999) and OTCandidate Chains (McCarthy 2007). The opacity argument for strata is weak because it reduces to the demonstration that Stratal OT can account for opacity by invoking one mechanism (strata/levels) while Standard OT uses several unrelated mechanisms, so is not homogeneous. The point of this paper is that strata/levels are motivated by different inventories, so the type of admissible segments at the stem level is different from the type of admissible segments at the word level and that, in turn, is different from the type of admissible segments at the postlexical level. Inventory arguments are important because they are not amenable to restatement in terms of OT auxiliary theories. Selecting Surface Velar Palatalization for making the inventory argument is a good choice because the process unveils massive differences in inventories at level 1 , level 2 and level 3.

The second point of this paper-derived environments - brings up two issues: first, the issue of how derived environments (DE, henceforth) should be expressed formally and, second, the issue of the life cycle of a historical process. It is argued that the role of derived environments is best defined as a constraint that, like any OT constraint, can be ranked differently at different levels in Stratal OT. A historical analysis of Surface Velar Palatalization tells the story of how the process came into being and operated for centuries in an unrestricted way. It subsequently became restricted to derived environments, which led to pronunciation reversals of the historical Duke-ofYork type: $g \varepsilon \rightarrow g^{j} \varepsilon \rightarrow g \varepsilon$.

\footnotetext{
${ }^{1}$ The term Surface Velar Palatalization is used in this paper to refer to the palatalization of velars before $e$. A broader process called Surface Palatalization refers to the palatalization of all consonants, including velars, before $i$ and $j$ (see Gussmann 1980 and Rubach 1984).

${ }^{2}$ The literature (beginning with Steele 1973) has extensive discussion of palatalization of velars before /i/: $k g x \rightarrow k^{j} g^{j} x^{j}$, since this is a classic, totally exceptionless allophonic rule. In contrast, the context of $/ \varepsilon /$ is problematic because it appears to be ridden with exceptions, morphological conditions, and so forth. This might be the reason why Surface Velar Palatalization triggered by $/ \varepsilon /$ has been neglected in the literature.
} 
This article is organized as follows. Section 1 introduces the relevant background facts of Polish phonology (Sect. 1.1) and the assumptions of Stratal OT (Sect. 1.2). Section 2 discusses Phonemic Velar Palatalization while Sect. 3 provides an OT analysis of Surface Velar Palatalization and related processes, making the point about segment inventory constraints and derived environments. Section 4 looks at a historical development of Surface Velar Palatalization from Old Polish, through Middle Polish, to Modern Polish. Section 5 summarizes the rankings of the constraints and their interaction. Section 6 concludes with a summary of the results. The Appendix extends the analysis to coronal and labial inputs and to $i$ as the trigger of Palatalization.

\section{Background}

This section prepares the ground for an analysis of Velar Palatalization. I begin with the presentation of descriptive facts of Polish phonology in the fragment that is relevant for this article. Subsequently, I introduce the assumptions of Stratal OT and the constraint apparatus for an analysis of Palatalization.

\subsection{Descriptive background}

Polish has a rich system of consonants. One reason for this richness is that the distinction 'hard' versus 'soft' consonants cuts without exception across the whole system. According to Wierzchowska (1963:9-11 and 1971:149), hard consonants are pronounced with a tongue body configuration for the back vowel [a] while soft consonants have a tongue body position characteristic for front vowels. Consequently, in terms of features, hard consonants are characterized as [+back] while soft consonants are [-back]. In (1), I look at a fragment of the phonetic inventory that includes coronals and dorsals. For compactness, I list only voiceless obstruents, noting that $[\mathrm{x}]$ has a voiced counterpart only as a result of Voice Assimilation. I assume the Halle-Sagey model of Feature Geometry (Halle 1992; Sagey 1986), in which the features [ \pm anterior] and [ \pm strident] are dependents of the CORONAL node, so they are not applicable to dorsals.

(1) Surface coronal and dorsal obstruents in Polish

\begin{tabular}{|l|c|c|c|c|c|c|c|c|c|c|c|c|c|c|c|c|}
\hline \multicolumn{10}{|c|}{ C O R O N } & \multicolumn{10}{|c|}{ D O R S } \\
\hline & $\mathrm{t}$ & $\mathrm{t}^{\mathrm{j}}$ & $\mathrm{s}$ & $\mathrm{s}^{\mathrm{j}}$ & $\mathrm{t}$ & $\mathrm{t}^{\mathrm{j}}$ & $\int$ & $\int^{\mathrm{j}}$ & $\mathrm{t}$ & $\mathrm{f}^{\mathrm{j}}$ & $\mathrm{c}$ & $\mathrm{t} 6$ & $\mathrm{k}$ & $\mathrm{k}^{\mathrm{j}}$ & $\mathrm{x}$ & $\mathrm{x}^{\mathrm{j}}$ \\
\hline back & + & - & + & - & + & - & + & - & + & - & - & - & + & - & + & - \\
\hline contin & - & - & + & + & - & - & + & + & - & - & + & - & - & - & + & + \\
\hline anter & + & + & + & + & + & + & - & - & - & - & - & - & & & & \\
\hline strid & - & - & + & + & + & + & + & + & + & + & + & + & & & & \\
\hline
\end{tabular}

All of these consonants occur in the surface representation, as the following examples show. 


\section{(2) Hard versus soft consonants in Polish}

brat $[\mathrm{t}]$ 'brother' - brat Janka $\left[\mathrm{t}^{\mathrm{j}} \mathrm{j}\right]$ 'Janek's brother': zobacz [t] 'see' - zobacz je [ $\left.\mathrm{t}^{\mathrm{j}} \mathrm{j}\right]$ 'see them':

głos [s] 'voice' - głos Ireny [ $\left.\mathrm{s}^{\mathrm{j}} \mathrm{i}\right]$ 'Irena's voice':

dasz [f] 'give' - dasz je [j j] 'you will give them':

krok $[\mathrm{k}]$ 'step' - krok Ireny [k $\left.\mathrm{k}^{\mathrm{j}} \mathrm{i}\right]$ 'Irena's step':

duch $[\mathrm{x}]$ 'spirit' - duch Ireny $\left[\mathrm{x}^{\mathrm{j}} \mathrm{i}\right]$ 'Irena's spirit':

ciało [ tca] 'body':

siano [ca] 'hay': palatalized dental stop

palatalized postalveolar affricate

palatalized alveolar fricative

palatalized postalveolar fricative

prevelar stop

prevelar fricative

prepalatal affricate

prepalatal fricative

The feature theory shown in (1) fails to distinguish between palatalized postalveolar $\left[{ }^{\mathrm{j}} \mathrm{t}^{\mathrm{j}}\right]$ and prepalatal [ $\left.{ }_{6} \mathrm{t}_{6}\right]$. This issue has been debated in the phonetic literature, notably by Dogil (1990), Halle and Stevens (1997) and Żygis and Hamann (2003). Wierzchowska (1971) and Dogil (1990) note that $\left[\int 3 t \int d \int^{j} 3^{j} t^{j} \mathrm{~d}^{\mathrm{j}}\right]$ are pronounced with lip protrusion, which gives them a characteristic hushing quality that distinguishes them from $\left[\begin{array}{l}6 \\ z\end{array} t_{6} \mathrm{~d}_{6}\right]$. Sidestepping the exact nature of the relevant phonetic property, I will use the following segment inventory constraints:

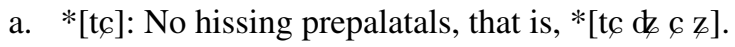

b. *[g]: No hushing postalveolars, that is, $*\left[\mathrm{t}^{\mathrm{j}} \mathrm{dg}^{\mathrm{j}} \int^{\mathrm{j}} z^{\mathrm{j}} \mathrm{t} \mathrm{d} \int \mathrm{\int}\right]$.

In contrast to the consonantal system, the vocalic system of Polish is simple. It includes the high vowels $[\mathrm{i} \mathrm{i} u],{ }^{3}$ the mid [ $\varepsilon$ o] and the low [a]. ${ }^{4}$ The only complication is that Polish has yers, the renowned Slavic vowels, which exhibit an alternation between $e[\varepsilon]$ and zero, as in bez 'lilac' (nom.sg.) $-b z+y$ (nom.pl.).

Analyzing yers is a perennial problem of Polish phonology. Rubach's (2016) study of the yers has been carried out in the framework of Stratal OT, so it connects with the analysis pursued here in a seamless way.

Rubach (2016) turns around the classic analysis of yers (Gussmann 1980; Rubach 1984) and argues that, first, Yer Deletion precedes Yer Vocalization and, second, Yer Deletion is context-sensitive while Yer Vocalization is context-free. Yer Deletion takes place in a CV context, meaning before a single consonant followed by a full vowel. ${ }^{5}$ Yers that have not been deleted 'vocalize' context-freely and become the regular vowel $[\varepsilon]$. This is illustrated in (4), where I look at the derivation of $b z+y$ 'lilac' (nom.pl.) and bez (nom.sg.). The yer is transcribed as the capital letter $E$.

$$
\begin{array}{ll}
\text { a. } & \text { Yer Deletion } / / \mathrm{bEz}+\mathrm{i} / /^{6} \rightarrow[\mathrm{bzi}] \\
\text { b. } & \text { Yer Vocalization } / / \mathrm{bEz} / / \rightarrow[\mathrm{b} \varepsilon \mathrm{s}]
\end{array}
$$

\footnotetext{
${ }^{3}$ For the status of $[\mathrm{i}]$ as the underlying segment, see Rydzewski (2017).

${ }^{4}$ It is unclear if the nasal vowels spelled $\varepsilon$ and $a$ should be analyzed as deriving from strings of an oral vowel and a nasal consonant or whether they should be regarded as underlying segments. See Rubach (1984).

${ }^{5}$ The term 'full vowel' refers to any vowel that is linked to a mora.

${ }^{6}$ I use double slashes for underlying representations, single slashes from intermediate representations at levels 2 and 3, and square brackets for surface representations.
} 
In (4a), the yer is followed by a consonant and a vowel, and hence deletes. This context does not occur in (4b), so Yer Deletion is mute and, consequently, the yer vocalizes. Rubach (2016) argues that Yer Deletion takes place at level 2 while Yer Vocalization happens at level 3. Looking at the examples in (4), the inputs to level 3 are the structures $/ \mathrm{bz} \dot{\mathrm{i}} /$ and $/ \mathrm{bEz} /$. The former has no yer any more, so [bzi] is the final output. The latter vocalizes its yer and surfaces as [bes], where //z// $\rightarrow[\mathrm{s}]$ is an effect of Final Devoicing.

A further question is what the symbol //E// actually stands for. It cannot be a regular vowel $[\varepsilon]$ because $/ / \varepsilon / /$ contrasts with $/ / \mathrm{E} / /$ in that the deletion is unpredictable, as the following minimal pairs show.

$$
\begin{aligned}
& \text { bez [bes] 'meringue' (gen.pl.) - bez+y [bezi] (nom.pl.) } \\
& \text { bez [bes] 'lilac' (nom.sg.) - - bz+y [bzi] (nom.pl.) } \\
& \text { kier } \left.\left[\mathrm{k}^{\mathrm{j}} \varepsilon \mathrm{r}\right] \text { 'hearts' (nom.sg.) - kier+y [ } \mathrm{k}^{\mathrm{j}} \varepsilon \mathrm{ri}\right] \text { (nom.pl.) } \\
& \text { kier }\left[\mathrm{k}^{\mathrm{j}} \mathrm{cr}\right] \text { (gen.pl.) } \\
& \text { - } \mathrm{kr}+\mathrm{y} \text { [kri] 'icefloats' }
\end{aligned}
$$

The conclusion is that the yer $\varepsilon$ and the regular vowel $\varepsilon$ must be distinct in terms of their underlying representation. There is voluminous literature on how this distinction should be made. ${ }^{7}$ The analysis in Rubach (2016) builds on the idea of floating segments. Specifically, the yer $\varepsilon$ differs from the regular vowel $\varepsilon$ by lacking a mora. Yer Vocalization is therefore a process that inserts a mora, making the yer $\varepsilon$, transcribed $/ / \mathrm{E} / /$, indistinguishable from the regular vowel $\varepsilon$.

\subsection{Theoretical background: Derivational Optimality Theory}

Derivational OT (Rubach 1997, 2011, 2016) is a version of Stratal OT (Kiparsky 1997, 2000, 2015; Bermúdez-Otero 1999, 2007, 2018). It is different from Stratal OT in one respect only: the assumption is that the grammar by default has four levels or strata. Stratal OT recognizes three levels/strata: the stem level, the word level and the postlexical level. Derivational OT adds a fourth level: the clitic level that is placed between the word level and the postlexical level.

The stem level encompasses the root and level 1 affixes. The word level enlarges the domain of analysis by adding level 2 affixes to the structures derived at the stem level. The determination which affixes are level 1 and which are level 2 is a language-specific matter. Similarly, languages may differ in their understanding of what constitutes a clitic structure. For example, Rubach (2016) argues that prefixes in Polish have the status of clitics, ${ }^{8}$ hence prefix plus word structures are analyzed at level 3. The postlexical level, level 4, covers the domain of the utterance, analyzing processes that apply across word boundaries. The input to level 1 is the underlying representation, the input to level 2 is the optimal output from level 1 , the input to level 3 is the winner from level 2, and the winner from level 3 is the input to level 4. In effect then, the architecture of Derivational OT is cyclic be-

\footnotetext{
${ }^{7}$ See, for example, Bethin (1992), Czaykowska-Higgins (1988), Gussmann (1980), Kenstowicz and Rubach (1987), Laskowski (1975), Lightner (1963), Rubach (1986, 2013) and Spencer (1986).

${ }^{8}$ This claim is not as radical as it might appear to be because prefixes in Slavic languages come historically from prepositions.
} 
cause the derivation proceeds from smaller domains to progressively larger domains: stem $\rightarrow$ word $\rightarrow$ clitic phrase $\rightarrow$ utterance. There is an obvious and actually intended similarity between Derivational OT and Lexical Phonology (Kiparsky 1982; Booij and Rubach 1987). Like in Lexical Phonology, at each cycle constraints can look at the structure derived in the previous cycle. However, unlike in Lexical Phonology, there is no prohibition to change the representations derived in an earlier cycle. Constraints are the same at all levels but their ranking may be different. The principle of reranking minimalism (Rubach 2000b) makes sure that reranking of the constraints occurs only if required by compelling analytical need. In sum, the grammar is understood as a system of four levels that are connected serially. Each level constitutes an OT 'miniphonology,' which means that it has its own inputs and constraint ranking. The Standard OT's principle of strict parallelism (simultaneous evaluation, no derivational steps) holds inside a level but not across levels since, as just explained, levels are ordered serially.

From the point of view of OT, Slavic Palatalization is driven by markedness constraints that are individualized with regard to the trigger. ${ }^{9}$
a. PAL- $i$
A consonant and a following high vowel must agree in [ \pm back].
b. PAL-e A consonant and a following mid vowel must agree in [ \pm back].
c. PAL-Glide
A consonant and a following glide must agree in $[ \pm$ back $]$.

PAL constraints mandate agreement in the feature $[ \pm$ back], so, for example, PAL$i$ is violated by the output [Ci] because the consonant is hard, i.e. [+back], while the vowel is front, i.e. [-back]. This violation can be removed in two ways. First, the consonant can undergo Palatalization, $\mathrm{Ci} \rightarrow C^{j} i$, or the vowel can undergo Retraction, $\mathrm{Ci} \rightarrow \mathrm{C} \dot{\mathrm{i}}$, where [i] is a [+back] vowel in terms of featural classification.

The architecture of OT requires that markedness constraints, here the constraints in (6), be controlled in their operation by faithfulness constraints. The relevant constraints evaluate the occurrence of [-back] and [+back] vowels as well as reflect the traditional bifurcation in Slavic languages into 'hard' and 'soft' consonants expressed as the opposition of [+back] for hard consonants and [-back] for soft consonants (Rubach 2003).

$$
\begin{array}{ll}
\text { a. IDENT-C }[+ \text { back }] & \begin{array}{l}
{[+ \text { back] on the consonant in the input must be preserved on }} \\
\text { a correspondent of that consonant in the output. }
\end{array} \\
\text { b. IDENT-C[-back] } & \begin{array}{l}
\text { [-back] on the consonant in the input must be preserved on } \\
\text { a correspondent of that consonant in the output. }
\end{array}
\end{array}
$$

\footnotetext{
${ }^{9}$ Rubach (2000a, 2003 and 2017), who postulated these constraints, argues that it would be empirically incorrect to postulate one general PAL constraint. For example, Ukrainian has Palatalization before [i] but not before [ $\varepsilon$ ] and [j] (Bilodid 1969). I argue in this paper that in a single language, Polish, Palatalization may have different triggers at different levels of derivation. Specifically, PAL- $e$ is active at levels 1 and 2 but inert at levels 3 and 4 while PAL-Glide and PAL- $i$ are active at all levels. Chen (1973) argues that there is an entailment relation between Palatalization rules specified for particular environments, whereby Palatalization before a low vowel entails Palatalization before a mid vowel and Palatalization before a mid vowel entails Palatalization before a high vowel.
} 
c. IDENT-V[-back] [-back] on the vowel in the input must be preserved on a correspondent of that vowel in the output.

d. IDENT-V[+back] [+back] on the vowel in the input must be preserved on a correspondent of that vowel in the output. ${ }^{10}$

Palatalization as a strategy of conflict resolution is grounded in phonetics, both articulatory and acoustic. Kochetov (2016) points out that fronting and raising of the tongue body is in conflict with gestures that articulators need to execute to produce consonants with various places and manners of articulation. He further argues that the sequence of a consonant plus a front vowel or a glide is both acoustically and perceptually problematic "as front vowels tend to obscure phonetic cues to place of articulation and induce affrication, ultimately leading to perceptual confusion" (Kochetov 2016:4, see also Ohala 1978; Kawasaki 1982; Guion 1996).

This article analyzes Palatalization of velar consonants in Polish, with a focus on the surface $k g \rightarrow k^{j} g^{j}$ Palatalization. To keep the presentation within manageable bounds, I look at the operation of PAL- $e$ and ignore PAL- $i .{ }^{11}$ This operation manifests itself in two ways that appear to be contradictory.

$$
\begin{aligned}
& \text { a. Phonemic Velar Palatalization } \mathrm{kg} \mathrm{x} \rightarrow \mathrm{tg} f \int /-\varepsilon \\
& \text { Example: ry } k[\mathrm{k}] \text { 'scream' }(\mathrm{N})-\mathrm{ryc} z+e+\mathrm{c}[\mathrm{tg} \varepsilon] \text { 'to scream' } \\
& \text { b. Surface Velar Palatalization } \mathrm{kg} \rightarrow \mathrm{k}^{\mathrm{j}} \mathrm{g}^{\mathrm{j}} /-\varepsilon \\
& \text { Example: cukier }\left[\mathrm{k}^{\mathrm{j}} \varepsilon\right] \text { 'sugar' (nom.sg.) - cukr+u [k] (gen.sg.) }
\end{aligned}
$$

There are two kinds of Palatalization that I dub Phonemic Velar Palatalization (8a) ${ }^{12}$ and Surface Velar Palatalization (8b). The former makes profound changes by turning velars into strident coronals, $k g \rightarrow t g d$. The latter executes a minor alteration turning velars into prevelars, $k g \rightarrow k^{j} g^{j}$.

In the case of PAL-e, the repair of the violation in $[\mathrm{C} \varepsilon]$ is implemented as Palatalization, schematically, //Ce// $\rightarrow\left[\mathrm{C}^{\mathrm{j}} \varepsilon\right]$, rather than as Vowel Retraction. The reason is that Vowel Retraction acting on $/ \varepsilon /$ as the input would derive schwa, $\varepsilon \rightarrow$ ə / $C[+b a c k]-$, like we have $i \rightarrow \dot{i} / C[+b a c k]$-in the case of PAL- $i$ (see above and Appendix). This action is blocked because schwa does not exist in Polish.

To conclude, PAL-e manifests itself in Polish as Palatalization, not as Vowel Retraction, a generalization that is expressed by the ranking of IDENT-V[-back] higher than PAL- $e$ and IDENT-C[+back]. In what follows, I will not consider Vowel Retraction candidates such as [kə] from the input $/ \mathrm{ke} / .^{13}$

\footnotetext{
${ }^{10}$ This system of IDENT constraints predicts four responses to, for example, PAL- $i$. If the input is /Ci/, then, as noted, there are two repairs: Palatalization, $C i \rightarrow C^{j} i$, and Vowel Retraction, $C i \rightarrow C \dot{ }$. If the input is $/ \mathrm{Cj}_{\mathrm{i}}$ /, then, there are two other repairs: Depalatalization, $C^{j} \dot{i} \rightarrow C \dot{i}$, and Vowel Fronting, $C^{j} \dot{i} \rightarrow C^{j} i$. All of these repairs are attested, albeit not all in a single language. See Rubach (2000a, 2007 and 2017) for discussion.

${ }^{11}$ In response to a reviewer's question, PAL- $i$ is discussed in the Appendix.

${ }^{12}$ This rule is known in the generative literature as First Velar Palatalization (Steele 1973; Gussmann 1980; Rubach 1984, and others). I introduce the data under a different name to emphasize the fact that the analysis using OT as the framework departs in fundamental ways from the rule-based analyses found in the literature. As the name First Velar Palatalization suggests, there is also Second Velar Palatalization, which fronts posteriors to dentals in morphologically specified contexts (see Rubach 1984 for a comprehensive analysis).

${ }^{13}$ The candidate $[\mathrm{k}$ ] would violate IDENT[ \pm round], an undominated constraint in Polish.
} 


\section{Phonemic Velar Palatalization}

As noted in (8), velars palatalize in two different ways that I call Phonemic Velar Palatalization $\left(k g x \rightarrow t j \delta\right.$ ) and Surface Velar Palatalization $\left(k g \rightarrow k^{j} g^{j}\right)$. This section looks at the former type of Palatalization in an effort to disentangle the two types of changes.

\begin{tabular}{|c|c|c|}
\hline $\mathrm{k} \rightarrow \mathrm{tg}$ & ryk [k] 'scream' $(\mathrm{N})$ & ry $c z+e+c ́[t f \varepsilon]$ 'to scream' \\
\hline & tłuk+ą $[\mathrm{k}]$ 'they break' & tłucz+esz [t $\varepsilon]$ 'you break' \\
\hline & człowiek [k] 'man' (nom.sg.) & człowiecz+e $[\mathrm{t} \varepsilon \mathrm{c}]$ (voc.sg.) \\
\hline & & człowiec $z+e \mathrm{k}[\mathrm{f} \varepsilon]$ (dimin.) \\
\hline & & człowie $c z+e n ́ s t w+o\left[t \int \varepsilon\right]$ 'humanity' \\
\hline $\mathrm{g} \rightarrow \mathrm{d}^{14}$ & mózg [sk] 'brain' & 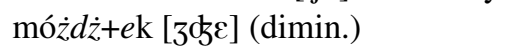 \\
\hline & miazg+a [zg] 'pulp' & $\operatorname{mia} \dot{z} d \dot{z}+e \mathrm{n}+\mathrm{ie}\left[3^{d} \xi \varepsilon\right]$ 'crushing' \\
\hline $\mathrm{x} \rightarrow \int$ & słuch $[\mathrm{x}]$ 'hearing' & słys $s+e+c$ ć $\left[\int \varepsilon\right]$ 'to hear' \\
\hline & dach $[\mathrm{x}]$ 'roof' & das $z+e \mathrm{k}\left[\int \varepsilon\right]$ (dimin.) \\
\hline
\end{tabular}

PAL-e, which is the driver for the alternations in (9), expresses a general Palatalization process that affects not only velars but also other types of consonants, as the following sample of representative examples shows.

$\begin{array}{llll}\text { nom.sg. } & \text { voc.sg. } & \text { type of change } & \text { gloss } \\ \text { brat }[\mathrm{t}] & \text { bractie }[\mathrm{t} c+\varepsilon] & \mathrm{t} \varepsilon \rightarrow \mathrm{t} c \varepsilon & \text { 'brother' } \\ \operatorname{los}[\mathrm{s}] & \operatorname{los}+i e[6+\varepsilon] & \mathrm{s} \varepsilon \rightarrow 6 \varepsilon & \text { 'lot' } \\ \text { dzwo } n[\mathrm{n}] & \text { dzwon+ie }[\mathrm{n}+\varepsilon] & \mathrm{n} \varepsilon \rightarrow \mathrm{j} \varepsilon & \text { 'bell' } \\ \text { chło }[\mathrm{p}] & \text { chło } p+i e\left[\mathrm{p}^{\mathrm{j}}+\varepsilon\right] & \mathrm{p} \varepsilon \rightarrow \mathrm{p}^{\mathrm{j}} \varepsilon & \text { 'farmer' } \\ \text { cham }[\mathrm{m}] & \text { cham } m+i e\left[\mathrm{~m}^{\mathrm{j}}+\varepsilon\right] & \mathrm{m} \varepsilon \rightarrow \mathrm{m}^{\mathrm{j}} \varepsilon & \text { 'cad' }\end{array}$

The outputs of Palatalization before $\varepsilon$ in (10) are invariably the phonetically soft (that is, [-back]) consonants. This is expected as Palatalization spreads the feature [-back] from $/ \varepsilon /$ to the consonant. Unexpectedly, however, the outputs given earlier in (9) are the hard (that is [+back]) consonants: [ $\left.\mathrm{t} d \mathrm{~d} \int\right]$.

Since PAL-e spreads [-back], the outputs must be the soft $\left[\mathrm{t}^{\mathrm{j}} \mathrm{d}^{\mathrm{j}} \int^{\mathrm{j}}\right]$. The derivation of the hard $\left[\mathrm{t} d \mathrm{~d} \int\right]$ is an effect of an independent process that I call Hardening (HARD). In terms of OT, Hardening is a segment inventory constraint.

(11) HARD $\left[\mathrm{f} d \iint 3\right]$ must be hard (that is, $[+$ back $]$ ).

HARD is a well-known generalization in Slavic languages (Rubach 2003). The details are different in different languages, for example, in Russian [ 3 ] are hard but [ $\mathrm{g}]$ is soft (Avanesov 1968).

The co-existence of PAL- $e$ and HARD in a single language creates an analytical problem for Standard OT. PAL-e requires agreement in [-back] between the con-

\footnotetext{
${ }^{14}$ The change $g \rightarrow o$ occurs if $/ \mathrm{g} /$ is preceded by an obstruent. In the remaining contexts, / $\mathrm{g} /$ spirantizes to [3], as in Bóg [k] 'God' (nom.sg.) - Boż+e (voc.sg.): //bog $+\varepsilon / / \rightarrow / b o d z \varepsilon / \rightarrow$ [boze]. See Rubach (1984, 2003), Łubowicz (2002) and Wolf (2008) for an analysis.
} 
sonant and [ع] while HARD bans [-back] stridents. The contradiction is solved by assuming that PAL-e and HARD operate on different levels of derivation, an analysis that is afforded by Derivational OT. Specifically, PAL-e, but not HARD, is active at level 1, so PAL-e is ranked high while HARD is bottom-ranked. At level 2, HARD

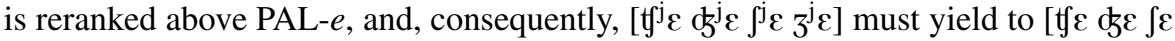
$3 \varepsilon$ ], even though these outputs violate PAL-e.

Given the input $/ / \mathrm{k}+\varepsilon / /$, as in $r y c z+e+c$ [ $\mathrm{rit}+\mathrm{f}+\mathrm{t} 6]$ 'to scream', a verb derived from $r y k$ 'scream', the analysis must make sure that $/ / \mathrm{k} \varepsilon$ ge $\mathrm{x} \varepsilon / /$ change into $/ \mathrm{t}^{\mathrm{j}} \mathrm{o}^{\mathrm{j}} \mathrm{j}^{\mathrm{j}} /$, and not into some other segments. In particular, it is necessary to exclude $/ \mathrm{k}^{\mathrm{j}} \varepsilon \mathrm{g}^{\mathrm{j}} \varepsilon \mathrm{x}^{\mathrm{j}} \varepsilon /$, which satisfy PAL-e by sharing [-back]. The desired effect is achieved by ranking as undominated the segment inventory constraints in (12).
a. $* \mathrm{k}^{\mathrm{j}}$ : Don't be $k^{j}$
b. $*^{\mathrm{j}}$ : Don't be $g^{j}$
c. ${ }^{*} \mathrm{x}^{\mathrm{j}}$ : Don't be $x^{j}$.

Since, given the ranking, $/ \mathrm{k}^{\mathrm{j}} \varepsilon \mathrm{g}^{\mathrm{j}} \varepsilon \mathrm{x}^{\mathrm{j}} \varepsilon /$ are not viable winners in the evaluation driven by PAL-e, the query is to what segments the inputs //ke ge xe// will change. The default would be $/ \mathrm{t}^{\mathrm{j}} \varepsilon \mathrm{d}^{\mathrm{j}} \varepsilon \mathrm{s}^{\mathrm{j}} \varepsilon /$ as coronals are less marked than labials ${ }^{15}$ and anteriors are better than posteriors. However, the facts of Polish show otherwise. In particular, palatalized coronals are preferably posterior (Rubach 2003), a generalization that is expressed as the following segment inventory constraint.

Posteriority (POSTER) Palatalized coronals must be posterior ([-anterior]).

That is, palatalized coronals must be [-anter]. This is exactly what we find in Slovak, where $\left[\underline{\mathrm{t}}^{\mathrm{j}}\right]$ is not just palatalized but also [-anter], which is marked as a minus underneath the $t$. However, posterior $t$ is not the desired output of Phonemic Velar Palatalization. We need to make sure that the outputs are strident consonants, //k g x// $\rightarrow / t^{\mathrm{j}} \mathrm{d}^{\mathrm{j}} \mathrm{j}^{\mathrm{j}} /$. This is effected by Stridency (Rubach 2007).

Stridency (STRID) Palatalized coronals must be [+strident].

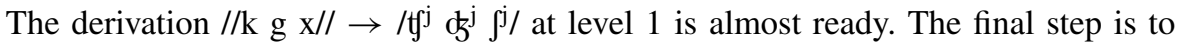
ensure that posterior stridents are the hushing stridents $\left[\mathrm{tg}^{\mathrm{j}} \mathrm{d}^{\mathrm{j}} \mathrm{f}^{\mathrm{j}}\right]$ and not the hissing stridents $\left[\mathrm{t}_{6} \& \mathrm{C}_{6}\right.$. The desired effect is achieved by ranking the segment inventory

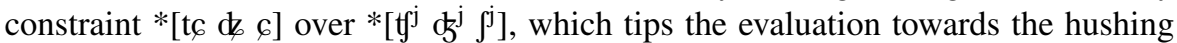
stridents. Lastly, turning dorsals into coronals violates IDENT-Dor.

IDENT-Dor The node DORSAL on the input segment must be preserved on a correspondent of that segment in the output.

The foregoing discussion is summarized in all essential points by looking at the evaluation of $r y c z+e+c / / \mathrm{rik}+\varepsilon+\mathrm{t} c / / \rightarrow[\mathrm{rit} f+\varepsilon+\mathrm{t} c]$ 'to scream', a verb derived from $r y k$ 'scream'. I look at the relevant fragment of the word.

\footnotetext{
${ }^{15}$ This follows from Prince and Smolensky's (2004) *LAB, *DOR $\gg *$ CORON that they proposed as the default ranking from the point of view of language typology.
} 


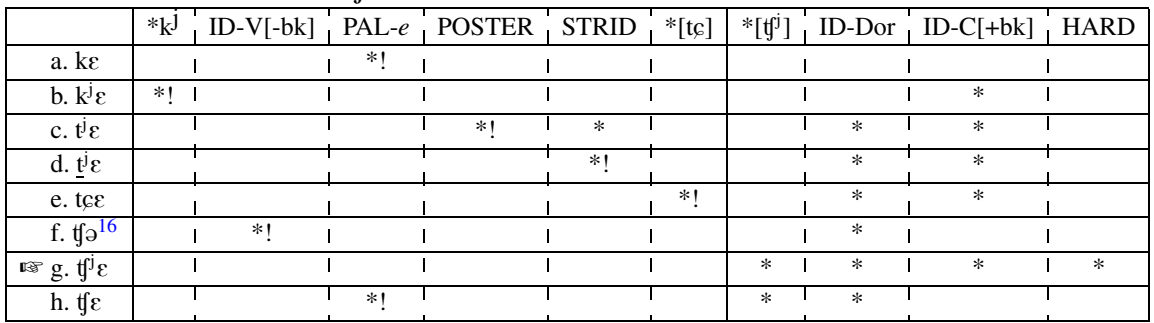

Obedience to PAL-e, like to any other Palatalization constraint, produces a soft [-back] consonant, which violates IDENT-C[+back]. The derivation is completed at

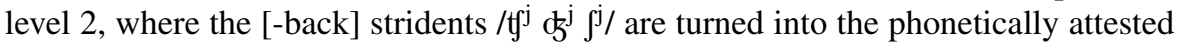
[+back] consonants through the action of HARD that is reranked to an undominated position.

Level $2 / \mathrm{f}^{\mathrm{j}} \varepsilon / \rightarrow[\mathrm{f} \varepsilon]$
\begin{tabular}{|r|c|c|c|}
\hline & HARD & IDENT-V[-back $]^{17}$ & PAL- $e$ \\
\hline a. $\mathrm{f}^{\mathrm{j}} \varepsilon$ & $* !$ & & \\
\hline b. $\mathrm{t} \varepsilon$ & & & $*$ \\
\hline c. $\mathrm{t} \partial$ & & $* !$ & \\
\hline
\end{tabular}

Coronal inputs, such as brat 'brother' - brac+ie [bratce] (voc.sg.) take a different derivational path from velar inputs. The problem is how to guarantee that //t// changes to $\left[t_{6}\right]$ and not to $\left[\mathrm{t}^{\mathrm{j}}\right]$, as we see in the velar input in (16). To achieve the correct result, we need to rerank the segment inventory constraints, as shown below.

$$
\text { Level 1: *[tc] } \gg *\left[\mathrm{t}^{\mathrm{j}}\right] \quad \text { versus Level } 2: *\left[\mathrm{t}^{\mathrm{j}}\right] \gg *\left[\mathrm{t}_{6}\right]
$$

At level $1, / / b^{2} a t+\varepsilon / /$ palatalizes to $/ \mathrm{brat}^{\mathrm{j}} \varepsilon /$ but does not undergo the enhancement operation conducted by POSTER and STRID, or else $/ \mathrm{t}^{\mathrm{j}} /$ would end up as $\left[\mathrm{t}^{\mathrm{j}}\right]$. The soft dental $/ \mathrm{t} /$ is kept in place by faithfulness constraints.
a. IDENT[+anter]
[+anterior] on the input segment must be preserved on a correspondent of that segment in the output.
b. IDENT[-strid] [-strident] on the input segment must be preserved on a correspondent of that segment in the output.

These IDENT constraints outrank POSTER and STRID at level 1. They block $t^{j} \rightarrow$ $t f^{j}$, but are mute on $k \rightarrow t y^{j}$. The reason is that, as noted earlier, [ \pm anter] and [ \pm strid] are dependents of CORON, so they are mute on velar inputs.

The spell-out operation, $/ \mathrm{t}^{\mathrm{j}} / \rightarrow\left[\mathrm{t}_{6}\right]$ takes place at level 2 , where we witness the following rerankings. Importantly, the default posterior segment is now [tc] rather than $\left[f^{\mathrm{j}}\right]$.

\footnotetext{
${ }^{16}$ This candidate is eliminated by IDENT-V[-back] or, alternatively, as mentioned earlier, by the segment inventory constraint $*$ ( (no schwa).

${ }^{17}$ The ranking HARD $\gg$ IDENT-V[-back] is based on Vowel Retraction, /i/ $\rightarrow$ [i] after hard stridents; see the Appendix.
} 
Level 1: IDENT[+anter], IDENT[-strid] $\gg$ POSTER, STRID versus

Level 2: POSTER, STRID $\gg$ IDENT[+anter], IDENT[-strid]

Level 1: *[tc] $\gg *\left[\mathrm{t}^{\mathrm{j}}\right]$ versus Level 2: $*\left[\mathrm{t}^{\mathrm{j}}\right] \gg *\left[\mathrm{t}_{6}\right]$

The derivation of bractie 'brother' (voc.sg.) continues as follows.

(21) Level $2 /$ brat $^{\mathrm{j}} \varepsilon / \rightarrow$ [bratce $]$

\begin{tabular}{|c|c|c|c|c|c|c|c|}
\hline & POSTER & STRID & IDENT[+anter] & IDENT & {$[$ [-strid] } & $* t$ & $* \mathrm{t}_{6}$ \\
\hline a. brat $^{j} \varepsilon$ & $* !$ & $*$ & & 1 & & 1 & \\
\hline b. brat $\underline{t}^{\mathrm{j}} \varepsilon$ & & $* !$ & $*$ & I & & 1 & \\
\hline c. brats ${ }^{j} \varepsilon$ & $* !$ & I & & I & $*$ & 1 & \\
\hline d. bratg $^{j} \varepsilon$ & & & * & * & * & i $*$ & \\
\hline e. bratce & & I & $*$ & I & * & 1 & $*$ \\
\hline
\end{tabular}

Finally, the operation of PAL-e is restricted to derived environments (DE, henceforth) in the sense that the consonant and the $/ \varepsilon /$ must span a morpheme boundary. This condition is fulfilled by the examples in (9) and (10) but not by those in (22) below. Morpheme-internal //Ce// remains unaffected and surfaces as $[\mathrm{C} \varepsilon]$ in violation of PAL-e. This generalization extends to all types of consonants, not just to dorsals.
a. Dorsals: kelner [ke] 'waiter' gem $[\mathrm{g} \varepsilon]$ 'game'
b. Coronals: teść [te] 'father-in-law' chełp+i+ć się [xe] 'boast' deszcz [de] 'rain'
ser [se] 'cheese'
c. Labials: berł+o [be] 'scepter'
pewien $[\mathrm{p} \varepsilon]$ 'sure' wesol+y [ve] 'happy'

It is unclear how the DE restriction can be built into an OT analysis and I will not pursue this issue here. ${ }^{18}$ One way would be to make reference to a morpheme boundary in the statement of a given PAL constraint. This approach is problematic in three ways. First, Rubach (1984) has shown that Palatalization in all contexts, not just before $e$, may carry a DE restriction. Translated into the OT framework, this observation would mean that DE needs to be written into three separate constraints: PAL-e, PAL- $i$ and PAL-Glide. Second, the founding assumption of OT is that constraints are universal, so there is no sense in which PAL- $e$ is a Polish constraint. For example, PAL- $e$ belongs just as much to Russian phonology as it does to Polish phonology. Writing DE into the statement of PAL-e would make the prediction that the DE restriction holds for Russian, like it does for Polish. The prediction is wrong because PAL$e$ freely applies morpheme-internally in Russian, as the following closely minimal contrasts show.

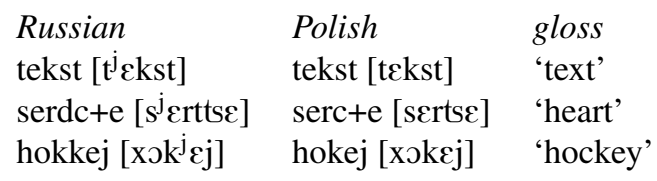

\footnotetext{
${ }^{18}$ There is a huge literature on this subject, including, inter alia, Antilla (2002, 2008), Hall (2006), Inkelas (2000), Itô and Mester (2003), Kiparsky (1993), Łubowicz (2002), McCarthy (2003), and Wolf (2008).
} 
I conclude that the putative DE-PAL- $e$ would not be able to deliver the correct results in Russian.

The third reason against building DE into particular PAL constraints stems from the observation that the same constraint in the same language can act as a DE generalization at one level but not at another level. This is what happens in the case of PAL-Glide. It is limited to DE at level 1 but not at level 2, where it applies morphemeinternally. I discuss this issue in Sect. 3.

The problems with the DE condition are eliminated if DE is divorced from particular PAL constraints and is stated as a constraint in its own right.

DE-PAL: A [-back] consonant and a front vowel/glide must span a morpheme boundary.

DE-PAL is subject to language-specific ranking, like any other constraint. ${ }^{19}$ Similarly, like other constraints, it can be reranked between levels. In Polish, the restriction of PAL- $e$ to derived environments means that the ranking is DE-PAL $\gg$ PAL- $e$. In Russian, the ranking is reversed, PAL- $e \gg$ DE-PAL, meaning that morphemeinternal palatalization is valued more highly than obedience to DE-PAL. The role of DE-PAL in Polish is illustrated by looking at the word seks 'sex' occurring in the loc.sg., whose suffix is //ع//. The surface representation contains unpalatalized [s] morpheme-internally and prepalatal [6] at a morpheme boundary: //scks+c// $\rightarrow$ $\left[\mathrm{sek}_{6}+\varepsilon\right]$. The evaluation is shown in $(25)$, where I look at the interaction between DE-PAL and PAL-e, ignoring the constraints that make sure that the output is the prepalatal $[6]$ rather than the palatalized $\left[\mathrm{s}^{\mathrm{j}}\right]$.

$/ / \mathrm{s} \varepsilon \mathrm{ks}+\varepsilon / / \rightarrow[\mathrm{s} \varepsilon \mathrm{k} c+\varepsilon]$
\begin{tabular}{|r|c|c|c|}
\hline & DE-PAL & PAL-e & IDENT-C[+back] \\
\hline a. $\mathrm{s} \varepsilon \mathrm{ks}+\varepsilon$ & & $* * !$ & \\
\hline b. $6 \varepsilon \mathrm{k} c+\varepsilon$ & $* !$ & & $* *$ \\
\hline c. $\mathrm{s} \varepsilon \mathrm{k} c+\varepsilon$ & & $*$ & $*$ \\
\hline
\end{tabular}

Candidate (25b) violates DE-PAL as there is no morpheme boundary between [6] and $[\varepsilon]$ in the root morpheme. This problem is repaired by candidate $(25 \mathrm{c})$ that leaves morpheme-internal [s] unpalatalized, so there is no violation of DE-PAL.

The question is what protects morpheme-internal sequences of a soft consonant and a front vowel from being eliminated in order to satisfy DE-PAL. These are the morphemes that have underlying soft consonants that come historically from the time when PAL- $e$ was not constrained by DE and applied across the board (Rubach 1984). The answer is that the potential adverse action of DE-PAL is thwarted by IDENT-C[back] that outranks DE-PAL. Thus, there is no danger that, for example, underlying //cerp//, sierp 'sickle', can lose its palatalization because the consonant and $[\varepsilon]$ are in the same morpheme and hence violate DE-PAL.

\footnotetext{
${ }^{19}$ DE-PAL is a separate constraint. It is not a clone of any specific PAL constraint because PAL constraints refer to specific triggers (PAL-e, PAL- $i$ and so forth) while DE-PAL checks for the string 'palatalized consonant and front vowel,' regardless of the source of the palatalized consonant.
} 
$/ / 6 \varepsilon r p / /=[6 \varepsilon r p]$ (no change)

\begin{tabular}{|r|c|c|}
\hline & IDENT-C[-back] & DE-PAL \\
\hline a. cerp & & $*$ \\
\hline b. serp & $* !$ & \\
\hline
\end{tabular}

The interaction between DE-PAL and PAL-Glide mentioned above creates no difficulty (see the next section). At level 1, DE-PAL $\gg$ PAL-Glide ensures that the candidate respecting DE is the winner. At level 2, the constraints are reranked, so PAL-Glide has jurisdiction not only at morpheme boundaries but also morphemeinternally. As will be shown in Sect. 4, DE-PAL makes sense not only for present day synchronic analysis but also for diachronic analysis because it permits to view historical change as constraint reranking.

A reviewer draws my attention to the fact that DE-PAL can be satisfied by depalatalizing a morpheme-internal consonant, as shown by the candidate [serp] in (26b). This option is closed in Polish by the ranking IDENT-C[-back] $\gg$ DE-PAL. The reverse ranking, DE-PAL $\gg$ IDENT-C [-back] would lead to depalatalization. This is exactly what we find in the history of Ukrainian. ${ }^{20}$ The word cited below means 'winter'.

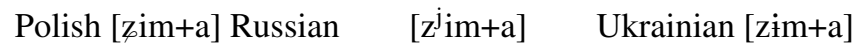

There is no doubt that the historical source is the form containing [i] and palatalized [ $\mathrm{z}^{\mathrm{j}}$ ], as in Modern Russian. That is, [zima] with [i] and hard [z] is a Ukrainian innovation (Shevelov 1979). The innovation can be readily accounted for if DE-PAL outranks IDENT-C[-back] and PAL- $i$ is ranked above IDENT-V[-back].

\begin{tabular}{|c|c|c|c|}
\hline & DE-PAL , PAL- $i$ & IDENT-C[-back] & IDENT-V[-back] \\
\hline a. $z^{\mathrm{j} i m+a}$ & $* !$ & & । \\
\hline b. $\mathrm{zim}+\mathrm{a}$ & $* !$ & $*$ & 1 \\
\hline c. $\mathrm{zim}+\mathrm{a}$ & 1 & $*$ & * \\
\hline
\end{tabular}

Recall that PAL- $i$ can be satisfied either by Palatalization, $C i \rightarrow C^{j}$, or by Vowel Retraction, $C i \rightarrow C \dot{i}$, as in either case the consonant and the vowel agree in [ \pm back]. DE-PAL is violated by (28a) because a palatalized consonant and a front vowel are not separated by a morpheme boundary.

The loc.sg. ending in Ukrainian is //i//, so the underlying representation of the loc.sg. form is $/ / \mathrm{z}^{\mathrm{j}} \mathrm{im}+\mathrm{i} / /$. The word illustrates the two effects of DE-PAL: Vowel Retraction morpheme-internally, $i \rightarrow \dot{i}$, and Palatalization at a morpheme boundary, $C \rightarrow C^{j}$.

\footnotetext{
${ }^{20}$ The evidence is diachronic because in Modern Ukrainian the historical $/ / \mathrm{z} \mathrm{j}$ i// has probably restructured as $/ / \mathbf{z} \mathbf{i} / /$.

${ }^{21}$ It is unclear if the $z$ is palatalized in the underlying representation. However, the argument stands also if the underlying representation is //zim+a// with hard //z//. The effect of DE-PAL is then different in an irrelevant way: DE-PAL blocks Palatalization instead of enforcing Depalatalization.
} 


\begin{tabular}{|c|c|c|}
\hline & DE-PAL , PAL- $i$ & $\begin{array}{l:l}\text { IDENT-C[-back] } & \text { IDENT-V[-back] }\end{array}$ \\
\hline a. $\mathrm{z}^{\mathrm{j}} \mathrm{im}+\mathrm{i}$ & $* !$ & 1 \\
\hline b. $\operatorname{zim}^{\mathrm{j}}+\mathrm{i}$ & ! $* !$ & $*$ \\
\hline c. $\mathrm{zim}^{\mathrm{j}}+\mathrm{i}$ & 1 & $*$ \\
\hline
\end{tabular}

The winner $\left[\mathrm{zim}^{\mathrm{j}}+\mathrm{i}\right]$ is exactly the attested surface representation in Ukrainian. I conclude that DE-PAL as a constraint is supported not only by the absence of Palatalization morpheme-internally, as in Polish (26), but also by Depalatalization, as in Ukrainian (28)-(29).

In sum, DE effects in Palatalization are captured by DE-PAL, a new constraint. Evidence for level distinction and hence for Derivational OT is drawn from the ranking paradoxes displayed by the segment inventory constraints: ${ }^{*} t_{6},{ }^{*} t^{j}$, POSTER and STRID.

\section{Surface Velar Palatalization}

The interaction between DE-PAL and PAL-e accounts for the absence of palatalization in (30), where the consonant and /ع/ occur inside one morpheme, as in ser [ssr] 'cheese'.

$/ / \mathrm{scr} / / \rightarrow[\mathrm{s} \varepsilon \mathrm{r}]$
\begin{tabular}{|c|c|c|c|}
\hline & DE-PAL & PAL-e & IDENT-C [+back] \\
\hline a. $\mathrm{scr}$ & & $*$ & \\
\hline b. $\operatorname{c\varepsilon r}$ & $* !$ & & $*$ \\
\hline
\end{tabular}

The problem is that the DE restriction cannot account for the absence of palatalization in the instr.sg. forms in (31) below. The examples are the same words as in (10), but this time we look not only at the voc.sg. but also at the instr.sg.

\begin{tabular}{|c|c|c|c|}
\hline m.sg. & voc.sg. & ins & gloss \\
\hline brat & bractie $[\mathrm{t} c+\varepsilon]$ & brat $t+e m[\mathrm{t}+\varepsilon \mathrm{m}]$ & 'brother' \\
\hline $\operatorname{los}[\mathrm{s}]$ & $\operatorname{los}+i e[c+\varepsilon]$ & $\operatorname{los}+e m[\mathrm{~s}+\varepsilon \mathrm{m}]$ & 'lot' \\
\hline dzwon $[\mathrm{n}]$ & dzwon+ie $[\mathrm{n}+\varepsilon]$ & dzwon+em $[\mathrm{n}+\varepsilon \mathrm{m}]$ & 'bell' \\
\hline $\operatorname{chłop}[\mathrm{p}]$ & chło $p+i e\left[\mathrm{p}^{\mathrm{j}}+\varepsilon\right]$ & chło $p+e m[\mathrm{p}+\varepsilon \mathrm{m}]$ & 'farmer' \\
\hline $\mathrm{ham}[\mathrm{m}]$ & cham+ie $\left[\mathrm{m}^{\mathrm{j}}+\varepsilon\right]$ & $\mathrm{cha} m+e m[\mathrm{~m}+\mathrm{\varepsilon m}]$ & 'cad' \\
\hline
\end{tabular}

These data show that the $e$ of the instr.sg. suffix -em does not induce Palatalization. The same is true of a few other suffixes in the declension of adjectives.

a. Masculine declension

$\begin{array}{lll}\text { gen.sg. } & \text { dat.sg. } & \text { gloss } \\ \text { grub } b+e g o[\mathrm{~b}+\varepsilon \mathrm{g} \supset] & \text { grub+emu }[\mathrm{b}+\varepsilon \mathrm{mu}] & \text { 'fat' } \\ \text { tłust } t+e g o[\mathrm{t}+\varepsilon \mathrm{g}) & \text { tłust } t+e m u[\mathrm{t}+\varepsilon \mathrm{mu}] & \text { 'greasy' } \\ \text { Likewise (same examples): } & \end{array}$


b. Feminine and neuter declension

neuter nom.sg. feminine gen.sg. fem/neuter nom.pl.

$\operatorname{gru} b+e[\mathrm{~b}+\varepsilon] \quad \operatorname{gru} b+e j[\mathrm{~b}+\varepsilon \mathrm{j}] \quad \operatorname{gru} b+e[\mathrm{~b}+\varepsilon]$

tłust $t+e[\mathrm{t}+\varepsilon] \quad$ tłus $t+e j[\mathrm{t}+\varepsilon \mathrm{j}] \quad$ tłus $t+e[\mathrm{t}+\varepsilon]$

c. Foreign agentive $-\mathrm{er}$

boks [s] 'boxing' - boks+er [s+er] 'boxer'

tos $t$ [t] 'toast' - tost + er $[\mathrm{t}+\varepsilon \mathrm{r}]$ 'toaster'

skan [n] 'scan' - skan+er [n+er] 'scanner'

The absence of palatalization in (31)-(32) is puzzling because the DE condition, a consonant and a vowel spanning a morpheme boundary, is fulfilled.

It appears that the suffixes in (31)-(32) must be marked as exceptions to Palatalization, but such marking cannot be correct, as the following examples show.

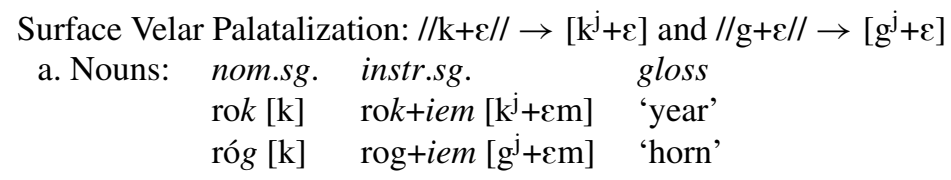

BUT no Surface Velar Palatalization with / $\mathrm{x} /$

b. Masculine adjectives:

$\begin{array}{lll}\text { gen.sg. } & \text { dat.sg. } & \text { gloss } \\ \text { wysok+iego }\left[\mathrm{k}^{\mathrm{j}}+\varepsilon g \supset\right] & \text { wysok+iemu }\left[\mathrm{k}^{\mathrm{j}}+\varepsilon \mathrm{mu}\right] & \text { 'tall' } \\ \mathrm{dłu} g+i e g o\left[\mathrm{~g}^{\mathrm{j}}+\varepsilon \mathrm{g} \rho\right. & \mathrm{dłu}+\text { iemu }\left[\mathrm{g}^{\mathrm{j}}+\varepsilon \mathrm{cmu}\right] & \text { 'long' }\end{array}$

BUT no Surface Velar Palatalization with /x/:

głuch+ego $[\mathrm{x}+\varepsilon \mathrm{go}] \mathrm{głu}$ ch + emu $[\mathrm{x}+\varepsilon \mathrm{mu}]$ 'deaf'

c. Likewise feminine and neuter adjectives (same examples): neuternom.sg. feminine gen.sg. fem/neuternom.pl. wysok+ie $\left[\mathrm{k}^{\mathrm{j}}+\varepsilon\right] \quad$ wysok+iej $\left[\mathrm{k}^{\mathrm{j}}+\varepsilon \mathrm{j}\right] \quad$ wysok+ie $\left[\mathrm{k}^{\mathrm{j}}+\varepsilon\right]$ $\mathrm{dłu} g+i e\left[\mathrm{~g}^{\mathrm{j}}+\varepsilon\right] \quad \mathrm{dłu} g+i e j\left[\mathrm{~g}^{\mathrm{j}}+\varepsilon \mathrm{j}\right] \quad \mathrm{dłu} g+i e\left[\mathrm{~g}^{\mathrm{j}}+\varepsilon\right]$

BUT no Surface Velar Palatalization with / $\mathrm{x} /$

$\mathrm{głu} c h+e[\mathrm{x}+\varepsilon] \quad \mathrm{głu} c h+e j[\mathrm{x}+\varepsilon \mathrm{j}] \quad \mathrm{głu} c h+e[\mathrm{x}+\varepsilon]$

d. Foreign agentive $-e r$

bank [k] 'bank' - bank+ier $\left[\mathrm{k}^{\mathrm{j}}+\varepsilon \mathrm{r}\right]$ 'banker'

pomag+a+ć $[\mathrm{g}]$ 'help' - pomag+ier $\left[\mathrm{g}^{\mathrm{j}}+\varepsilon \mathrm{r}\right]$ 'helper'

To conclude, the suffixes in (31)-(33) show a contradictory behavior: they are palatalizing for velar stops, but not for other types of consonants. Furthermore, the effect of Velar Palatalization is different from that seen before: //k $\mathrm{g} / /$ change to $\left[\mathrm{k}^{\mathrm{j}} \mathrm{g}^{\mathrm{j}}\right]$ rather than to [ $\mathrm{t} \mathrm{d}]$, as in $r y k$ [k] 'scream' (nom.sg.) - ryk+iem $\left[\mathrm{k}^{\mathrm{j}}+\varepsilon\right]$ (instr.sg.) versus $r y c z+e+c[t+\varepsilon]$ 'to scream'. The contradictions just outlined are resolved by Derivational OT without difficulty. The scenario is as follows.

The suffixes -em (instr.sg.), - ego (masc. gen.sg.), -ети (masc. dat.sg.), -e (neuter nom.sg.), $-e j$ (fem. gen.sg.), $-e$ (nom.pl.), and the foreign agentive $-e r$ are level 2 suffixes. This means that they are not available for evaluation at level 1 , which accounts for the absence of palatalization at level 1 in brat $+e m[t+\varepsilon m]$ 'brother' 


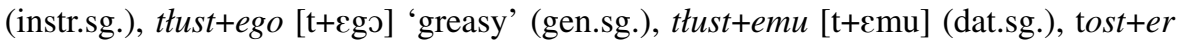
$[\mathrm{t}+\varepsilon \mathrm{r}]$ 'toaster', and so forth. ${ }^{22}$

An objection can be raised that the assignment of affixes to different levels is arbitrary. This is true and it reflects different historical sources that merged in the evolution of the language. The point is that Derivational OT has the resources to give a formal account of differences in the behavior of various affixes.

A reviewer points out that Standard OT could account for the behavior of level 2 suffixes by resorting to indexed constraints (Pater 2008). This is true, for example, an Output-Output faithfulness constraint OO-IDENT-Dor could be co-indexed with the instr.sg. suffix $/ / \mathrm{cm} / /$. The drawback of this solution is that it opens the way to analyses in which potentially every affix could have a phonology of its own, which hugely weakens the restrictiveness of the theory. Derivational OT assigns the problematic suffixes to a level and they cannot choose to which constraints they wish to be available. I conclude that level assignment is a more restrictive mechanism than Standard OT's indexed constraints and OO-faithfulness.

The question regarding the absence of palatalization returns at level 2, but the action of PAL-e is now severely curtailed. The curtailment is effected by the high ranking of the segment inventory constraints: *SOFT-Lab, banning palatalized labials, *SOFT-Coron, prohibiting [-back] coronals, and $* x^{j}$, banning the palatalized velar fricative.

\section{a. Level 1: ${ }^{\mathrm{j}} \mathrm{k}^{\mathrm{j}} * \mathrm{~g}^{\mathrm{j}} * \mathrm{x}^{\mathrm{j}} \gg$ PAL-e $\gg *$ SOFT-Lab, $*$ SOFT-Coron \\ b. Level 2: *SOFT-Lab, *SOFT-Coron, ${ }^{*} \mathrm{x}^{\mathrm{j}} \gg$ PAL-e $\gg * \mathrm{k}^{\mathrm{j}} * \mathrm{~g}^{\mathrm{j}}$}

At level 1, it is more important to obey PAL-e than the segment inventory constraints against soft labials and coronals (34a), so we have Palatalization of labials and coronals, exemplified in (10), such as chłop 'man' - chtop+ie $\left[\mathrm{p}^{\mathrm{j}}+\varepsilon\right]$ (voc.sg.) and brat 'brother' $-b r a c+i e$ [brat $6+\varepsilon$ ] (voc.sg.). At level 2, greater value is placed on obeying the segment inventory constraints in (34b) than obeying PAL-e, so Palatalization of labials, coronals and / $\mathrm{x} /$ before $/ \varepsilon /$ is blocked, as required by the data in (31)-(33).

At level 2, velar stops palatalize in a surface manner, $k g \rightarrow k^{j} g^{j}$, because the option of changing $/ \mathrm{kg} /$ to $[\mathrm{t} / \mathrm{d}]$ is closed by reranking IDENT-Dor to an undominated position. In (35), I look at the evaluation of krok+iem 'step' (instr.sg.) at level 2. Recall that $/ / \varepsilon \mathrm{m} / /$ is a level 2 suffix, so it was not available on level 1.

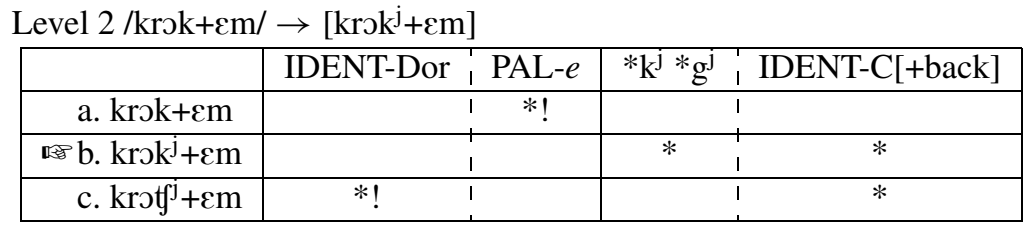

The blocking effect of the reranked constraints in (34b) is illustrated by pas+em [pasem] 'belt' (instr.sg.).

\footnotetext{
${ }^{22}$ The distinction between level 1 and level 2 affixes has a time-honored tradition in generative phonology. The idea is attributed to Siegel (1974). It played an important role in Lexical Phonology and was imported into OT by Benua (1997). The novelty of the analysis is that this distinction is applied to Polish, a solution that has never been proposed before.
} 
Level $2 /$ pas $+\varepsilon m /=[$ pas $+\varepsilon m]$ (no change)

\begin{tabular}{|r|c|c|}
\hline & *SOFT-Coron & PAL- $e$ \\
\hline a. pas $+\varepsilon \mathrm{m}$ & & $*$ \\
\hline b. pac $+\varepsilon \mathrm{m}$ & $* !$ & \\
\hline
\end{tabular}

There is no danger that the high-ranked *SOFT-Coron can undo the work done by

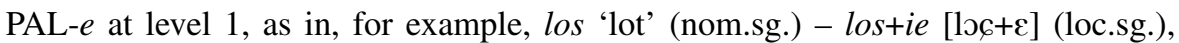
which leaves level 1 with the representation $/ \operatorname{los}^{j}+\varepsilon /{ }^{23}$ The integrity of the palatalized $/ \mathrm{s}^{\mathrm{j}} /$ or [6] is guarded by IDENT-C[-back] that is undominated at both level 1 and level 2.

$$
\text { Level } 2 / \mathrm{los}^{\mathrm{j}}+\varepsilon / \rightarrow[\mathrm{loc}+\varepsilon]
$$

\begin{tabular}{|r|c|c|c|c|}
\hline & IDENT-C[-back] & ${ }^{*}$ SOFT-Coron & PAL-e & Spell-out $^{24}$ \\
\hline a. $\operatorname{los}^{j}+\varepsilon$ & & $*$ & & $* !$ \\
\hline b. $\operatorname{lo} 6+\varepsilon$ & & $*$ & & \\
\hline c. $\operatorname{los}+\varepsilon$ & $* !$ & & $*$ & \\
\hline
\end{tabular}

The relationship between DE-PAL and PAL-e is copied unchanged from level 1 to level 2, which means that the ranking is DE-PAL $\gg$ PAL-e. The effect of the ranking is that the actual jurisdiction of PAL-e is limited to derived environments. This is exactly correct, as morpheme-internally, we find $[\mathrm{k} \varepsilon \mathrm{g} \varepsilon]$ rather than $\left[\mathrm{k}^{\mathrm{j}} \varepsilon \mathrm{g}^{\mathrm{j}} \varepsilon\right]$.

$$
\begin{aligned}
& \text { poker }[\mathrm{k} \varepsilon] \text { 'poker' legend }+\mathrm{a}[\mathrm{g} \varepsilon] \text { 'legend' } \\
& \text { kelner [ke] 'waiter' geograf+ia [ge] 'geography' } \\
& \text { kefir [ke] 'kefir' geometr+ia [ge] 'geometry' } \\
& \text { hokej [ke] 'hockey' gest [ge] 'gesture' }
\end{aligned}
$$

\begin{tabular}{|c|c|c|c|}
\hline & \begin{tabular}{l|l} 
IDENT-Dor & DE-PAL
\end{tabular} & PAL-e & IDENT-C[+back] \\
\hline a. poker & 1 & * & \\
\hline b. $\mathrm{pok}^{\mathrm{j}} \varepsilon \mathrm{r}$ & $* !$ & & * \\
\hline c. $p \operatorname{pot}^{\mathrm{j}} \varepsilon \mathrm{r}$ & $* !$ & & * \\
\hline
\end{tabular}

The constraint system predicts, correctly, that, for example, poker 'poker' is pronounced with $[\mathrm{k} \varepsilon]$ while rok+iem 'year' (instr.sg.) has the palatalized $\left[\mathrm{k}^{\mathrm{j}} \varepsilon\right]$, as the

\begin{tabular}{|c|c|c|c|c|}
\hline & IDENT-Dor & DE-PAL & PAL-e & IDENT-C [+back] \\
\hline a. $\mathrm{rok}+\varepsilon \mathrm{m}$ & & 1 & $* !$ & \\
\hline b. rok ${ }^{j}+\varepsilon m$ & & 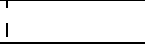 & & * \\
\hline c. $\operatorname{rot}^{\mathrm{j}}+\varepsilon \mathrm{m}$ & $* !$ & 1 & & * \\
\hline
\end{tabular}
following evaluations show.

ii. Level $2 / \mathrm{rok}+\varepsilon \mathrm{m} / \rightarrow\left[\mathrm{rok}^{\mathrm{j}}+\varepsilon \mathrm{m}\right]$

Recall that DE-PAL requires that a soft consonant and a front vowel span a morpheme boundary, a demand that is fulfilled in (39iib), [rok $\left.{ }^{j}+\varepsilon m\right]$, but not in (39ib), [pok $\left.{ }^{j} \varepsilon r\right]$.

\footnotetext{
${ }^{23}$ The spell-out operation, $/ \mathrm{s}^{\mathrm{j}} / \rightarrow[6]$, is effected at level 2; recall (20)-(21) in Sect. 2.

${ }^{24}$ The spell-out operation shown in (21) (the rankings POSTERIOR $\gg$ IDENT[+anter] and $*\left[\mathrm{t}^{\mathrm{j}}\right] \gg *\left[\mathrm{t}_{\mathrm{c}}\right]$ ), induces the change $/ \mathrm{s} / \rightarrow[6]$.
} 
The consequence of limiting PAL- $e$ to derived environments, DE-PAL $\gg$ PAL- $e$, is that morpheme-internal $\left[\mathrm{k}^{\mathrm{j}} \mathrm{g}^{\mathrm{j}}\right]$ are not derivable from $/ / \mathrm{k} \mathrm{g} / /$ any more and hence must be underlying segments, as the following sample of examples illustrates.

kiedy $\left[\mathrm{k}^{\mathrm{j}} \varepsilon \mathrm{di}\right]=/ / \mathrm{k}^{\mathrm{j}} \varepsilon \mathrm{di} / /$ 'when' kierat $\left[\mathrm{k}^{\mathrm{j}} \varepsilon \mathrm{rat}\right]=/ / \mathrm{k}^{\mathrm{j}} \varepsilon \mathrm{rat} / /$ 'treadmill' kier $\left[\mathrm{k}^{\mathrm{j}} \mathrm{cr}\right]=/ / \mathrm{k}^{\mathrm{j}} \mathrm{cr} / /$ 'hearts' zgiełk $\left[\mathrm{zg}^{\mathrm{j}} \boldsymbol{\varepsilon w k}\right]=/ / \mathrm{zg}^{\mathrm{j}} \boldsymbol{\varepsilon w k} / /$ 'turmoil' giemz+a $\left[\mathrm{g}^{\mathrm{j}} \mathrm{cmz}+\mathrm{a}\right]=/ / \mathrm{g}^{\mathrm{j}} \mathrm{cmz}+\mathrm{a} / /$ 'chamois' giermek $\left[\mathrm{g}^{\mathrm{j}} \mathrm{crm \varepsilon k}\right]=/ / \mathrm{g}^{\mathrm{j}} \mathrm{rm} \varepsilon \mathrm{k} / /$ 'page'

Similarly as in (26) and (37), DE-PAL cannot undo the palatalization on the input $/ / \mathrm{k}^{\mathrm{j}} \varepsilon / /$ and $/ / \mathrm{g}^{\mathrm{j}} \varepsilon / /$ since DE-PAL is kept in check by IDENT-C[-back].

Level $2 / \mathrm{k}^{\mathrm{j}} \varepsilon \mathrm{di} /=\left[\mathrm{k}^{\mathrm{j}} \varepsilon \mathrm{di}\right]$ (no change)
\begin{tabular}{|c|c|c|c|c|}
\hline & IDENT-Dor & IDENT-C[-back] & DE-PAL & PAL- $e$ \\
\hline a. $\mathrm{k}^{\mathrm{j}} \varepsilon \mathrm{di}$ & & $*$ & $*$ & \\
\hline b. $\mathrm{k} \varepsilon \mathrm{di}$ & & $*$ & & $*$ \\
\hline c. $\mathrm{t}^{\mathrm{j}} \varepsilon \mathrm{di}$ & $* !$ & & & \\
\hline
\end{tabular}

There are two points that merit underscoring. First, the occurrence of [k g] versus $\left[\mathrm{k}^{\mathrm{j}} \mathrm{g}^{\mathrm{j}}\right]$ cannot be predicted, as in poker [poker] 'poker' - kier $\left[\mathrm{k}^{\mathrm{j}} \mathrm{\varepsilon r}\right]$ 'hearts'. Therefore, $[\mathrm{k}]$ versus $\left[\mathrm{k}^{\mathrm{j}}\right]$ must be encoded in the underlying representation: //poker// and $/ / \mathrm{k}^{\mathrm{j}} \mathrm{cr} / /$. Second, the analysis upholds Kiparsky's (1993) observation that the derived environment restriction can hold not only at the first level of derivation but also at later levels. ${ }^{25}$ Specifically, PAL-e exhibits the DE limitation at both level 1 and level 2, as we have just seen. PAL-Glide to which we now turn substantiates a different theoretical point.

The action of PAL-Glide is limited to derived environments at level 1 but not at level 2, which shows that it would be ill-advised to write the DE restriction into the statement of PAL-Glide itself. The correct analysis treats the DE restriction as a constraint that I have dubbed DE-PAL. The ranking DE-PAL $\gg$ PAL-Glide postulated for level 1 restricts PAL-Glide to derived environments ${ }^{26}$ while the reranking to PAL-Glide $\gg$ DE-PAL postulated for level 2 lifts this restriction. The details of the analysis ensue below.

The examples below illustrate the so-called 'yers', that is, vowels that alternate with zero (recall Sect. 1.1.).

\begin{tabular}{|c|c|c|}
\hline nom.sg. & gen.sg. & gloss \\
\hline $\operatorname{kiep}\left[\mathrm{k}^{\mathrm{j}} \varepsilon \mathrm{p}\right]$ & $\mathrm{kp}+\mathrm{a}[\mathrm{kpa}]$ & 'fool' \\
\hline cukier $\left[\operatorname{tsuk}^{\mathrm{j}} \varepsilon r\right]$ & cukr+u [tsukru] & 'sugar' \\
\hline $\operatorname{giez}\left[\mathrm{g}^{\mathrm{j}} \varepsilon \mathrm{z}\right]$ & $\mathrm{gz}+\mathrm{a}$ [gza] & 'gadfly' \\
\hline ogień $\left[\operatorname{og}^{\mathrm{j}} \varepsilon \mathrm{n}\right]$ & ogn+ia [ogna] & 'fire' \\
\hline
\end{tabular}

\footnotetext{
${ }^{25}$ Kiparsky's observation refers to the cyclic level in Lexical Phonology (Kiparsky 1982; Booij and Rubach 1987), not to the stem level in Derivational OT, but there are many intended parallels between the two theories.

${ }^{26} \mathrm{PAL}-$ Glide at level 1 palatalizes, for example, //t// and //n// in czyst+y 'clean' - czyśc+iec [tc+ets] 'purgatory' and wygnan+y 'banished' (passive participle) - wygnan+iec 'outcast', the morpheme -iec //Ets// has a yer, compare the gen.sg. forms $c z y s ́ c+c+a$ and wygnańt $c+a$.
} 
b. Feminine and neuter nouns

$\begin{array}{lll}\text { nom.sg. } & \text { gen.pl. } & \text { gloss } \\ \mathrm{kr}+\mathrm{a}[\mathrm{kra}] & \text { kier }\left[\mathrm{k}^{\mathrm{j}} \mathrm{cr}\right] & \text { 'icefloat' } \\ \text { iskr+a [iskra] } & \left.\text { iskier [isk }{ }^{\mathrm{j}} \mathrm{\varepsilon r}\right] & \text { 'spark' } \\ \text { bagn+o [bagno] } & \text { bagien }\left[\mathrm{bag}^{\mathrm{j}} \mathrm{cn}\right] & \text { 'swamp' } \\ \text { igł+a [igwa] } & \left.\text { igieł [ig' }{ }^{\mathrm{j}} \mathrm{cw}\right] & \text { 'needle' }\end{array}$

As explained in Sect. 1.1 yers, transcribed //E//, are floating melodic segments at the underlying level, so Yer Vocalization is a process of mora insertion. Prior to mora insertion, the yer is a melodic segment that cannot erect a syllable itself precisely because it lacks a mora. This is exactly the structure that characterizes glides. In autosegmental theory, the glide [j], for example, is the vocalic melodic segment [i] that lacks a mora. To conclude, the yer is structurally identical to a glide and, consequently, must be treated as a glide. The difference between $/ / \mathrm{j} / /$ and $/ / \mathrm{E} / /$ is that $/ / \mathrm{j} / /$ is a high front glide while //E// is a mid front glide. The conclusion that matters for the analysis in this article is that Palatalization caused by yers falls under the jurisdiction of PAL-Glide, and not PAL-e.

The data in (42) represent a significant generalization that I state informally in (43).

$$
\text { Yers trigger Surface Velar Palatalization: } \mathrm{kg} \rightarrow \mathrm{k}^{\mathrm{j}} \mathrm{g}^{\mathrm{j}} /-\mathrm{E}
$$

This generalization is entirely exceptionless and fully productive. It extends to newly created yers, that is, to recent borrowings, as the following examples demonstrate.

$$
\begin{aligned}
& \text { Russian tager 'camp' } \rightarrow \text { Polish łagier }\left[\mathrm{g}^{\mathrm{j}} \mathrm{\varepsilon r}\right] \text {, a yer as }[\varepsilon] \text { alternates with zero } \\
& \text { in łagr }+y \text { (nom.pl.) } \\
& \text { English single } \rightarrow \text { Polish singiel }\left[\mathrm{g}^{\mathrm{j}} \mathrm{\varepsilon l}\right] \text { 'single person', a yer as }[\varepsilon] \text { alternates } \\
& \text { with zero in singl+e (nom.pl.) }
\end{aligned}
$$

Since, as already said, yers are formally glides, the responsibility for inducing Palatalization rests with PAL-Glide, not with PAL-e. This is fortunate because Palatalization before //E// and Palatalization before the regular vowel //ع// exhibit different behaviors. The latter, that is, PAL-e, applies in derived environments and is blocked morpheme-internally: recall the data in (33) and (38), such as rok 'year' (nom.sg.) rok+iem [rok $\left.{ }^{\mathrm{j}}+\mathrm{em}\right]$ (instr.sg.) versus poker [poker] 'poker'.

In contrast, PAL-Glide applies morpheme-internally, as in kiep [ $\left.\mathrm{k}^{\mathrm{j}} \varepsilon \mathrm{p}\right]$ 'fool' (nom.sg.) $-k p+a$ [kp+a] (gen.sg.) and ogień $\left[\mathrm{og}^{\mathrm{j}} \mathrm{g} \mathrm{j}\right]-$ ogn+ia [ogn+a] (gen.sg.). Translated into the constraint system, morpheme-internal application means that

\begin{tabular}{|c|c|c|c|}
\hline & Yer Del IDENT-Dor & PAL-Glide & $\begin{array}{lll}\text { DE-PAL } & \text { IDENT-C[+back] }\end{array}$ \\
\hline a. $\mathrm{kEp}$ & 1 & $* !$ & 1 \\
\hline b. $k^{j} \mathrm{Ep}$ & 1 & & * \\
\hline c. t $^{\mathrm{j}} \mathrm{Ep}$ & $* !$ & & * \\
\hline
\end{tabular}
PAL-Glide must outrank DE-PAL. The derivation of kiep 'fool' is therefore as follows.

Level $2 / \mathrm{kEp} / \rightarrow\left[\mathrm{k}^{\mathrm{j}} \varepsilon \mathrm{p}\right]$ 
Recall that Yer Deletion deletes //E// if followed by a consonant and a vowel, which is not the situation in (45), so /E/ survives in the optimal candidate at level 2. The winner from level $2, / \mathrm{k}^{\mathrm{j}} \mathrm{Ep} /$, is the input to level 3, at which yers vocalize, that is, obtain a mora and hence become nondistinct from the regular vowel $[\varepsilon]: / \mathrm{k}^{\mathrm{j}} \mathrm{Ep} / \rightarrow$ $\left[\mathrm{k}^{\mathrm{j}} \varepsilon \mathrm{p}\right]$.

The gen.sg. form $k p+a$ 'fool', from underlying //kEp+a//, loses its yer at level 2 because $E$ is followed by a consonant (here $p$ ) and a vowel (here $a$ ). Deleting the yer violates MAX-Seg that militates against deletion.

(46) Level $2 / \mathrm{kEp}+\mathrm{a} / \rightarrow[\mathrm{kp}+\mathrm{a}]$

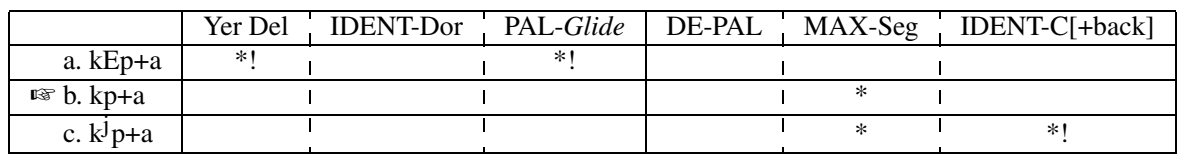

The analysis is correct as [kpa] is the attested surface form. It is worth underscoring that there is an advantage to doing Surface Velar Palatalization at level 2 rather than at level 1. The reason is that yers are deleted at level 2, which allows us to uphold the generalization that $/ \mathrm{kg}$ / are palatalized before yers but only before those yers that ultimately vocalize and are turned into $[\varepsilon]$ in the surface representation.

If Surface Velar Palatalization was done at level 1, hence prior to Yer Deletion, it would be necessary to postulate a Depalatalization constraint to depalatalize the stops at level 2. That is, $/ / \mathrm{kEp}+\mathrm{a} / / \rightarrow / \mathrm{k}^{\mathrm{j}} \mathrm{Ep}+\mathrm{a} /$ at level 1 and $/ \mathrm{k}^{\mathrm{j}} \mathrm{Ep}+\mathrm{a} / \rightarrow / \mathrm{k}^{\mathrm{j}} \mathrm{p}+\mathrm{a} / \rightarrow$ [kpa] at level 2. The Depalatalization step and the Depalatalization constraint are not necessary if Surface Velar Palatalization is executed at level 2, as proposed in this paper.

PAL-Glide operates not only at level 2 but also at level 1, as the following examples show. The suffix $-e k$ is a diminutive morpheme.

\begin{tabular}{|c|c|c|c|}
\hline & dimin. nom.sg. & dimin. gen.sg. & gloss \\
\hline $\mathrm{o} k[\mathrm{k}]$ & boczek $[\mathrm{f}+\varepsilon \mathrm{k}]$ & $\mathrm{boc} z+k+\mathrm{a}[\mathrm{t}+\mathrm{k}]$ & \\
\hline [sk] & mó $\dot{z} d \dot{z}+e k[\mathrm{~d}+\varepsilon \mathrm{k}]$ & móżḋ $+k+\mathrm{a}\left[\int \mathrm{t}+\mathrm{k}\right]$ & \\
\hline $\mathrm{ach}[\mathrm{x}]$ & $\operatorname{das} z+e k\left[\int+\varepsilon \mathrm{k}\right]$ & $\operatorname{das} z+k+\mathrm{a}\left[\int+\mathrm{k}\right]$ & 'roof' \\
\hline
\end{tabular}

The diminutive suffix $-e k$ contains a yer because $e$ alternates with zero in (47). The representation is therefore //Ek// and the palatalization effects are the action of PALGlide, not of PAL-e. The point is that the changes driven by PAL-Glide and the associated constraints are different at level 1 and at level 2.

$$
\text { Level 1: } \mathrm{kg} \mathrm{x} \rightarrow \mathrm{tg} \mathrm{d} / \mathrm{E} \text {, as shown in (47) }
$$

Level 2: $\mathrm{k} \mathrm{g} \rightarrow \mathrm{k}^{\mathrm{j}} \mathrm{g}^{\mathrm{j}} /-\mathrm{E}$, as shown in (42)

Further, the operation of PAL-Glide at level 1 leads to opacity in the surface representation. We see this in the gen.sg. forms in (49), for example, $b o c z+k+a$, the gen. sg. of bocz+ek 'side' (dimin.).

$$
\begin{aligned}
& \text { Level 1: //bok+EK+a// } \rightarrow / \text { bot }^{\mathrm{j}}+\mathrm{Ek}+\mathrm{a} / \\
& \text { Level 2: /bot }{ }^{\mathrm{j}}+\mathrm{Ek}+\mathrm{a} / \rightarrow \text { [botfka] }
\end{aligned}
$$


The trigger of Palatalization is not present in the surface representation, so the representation is opaque. In contrast, the outcomes produced by PAL-Glide at level 2 are fully transparent: we see $\left[\mathrm{k}^{\mathrm{j}} \mathrm{g}^{\mathrm{j}}\right]$ only in the forms that have the trigger of Palatalization present in the surface representation, so the $/ / \mathrm{k} / /$ is palatalized in kiep $\left[\mathrm{k}^{\mathrm{j}} \varepsilon \mathrm{p}\right]$ 'fool' (nom.sg.), but not in $k p+a$ [kpa] (gen.sg.): $/ / \mathrm{kEp} / / \rightarrow\left[\mathrm{k}^{\mathrm{j}} \varepsilon \mathrm{p}\right]$, with $k \rightarrow k^{j}$ at level 2, but $/ / \mathrm{kEp}+\mathrm{a} / / \rightarrow[\mathrm{kpa}]$, with [k] at level 2 .

It should also be noted that PAL-Glide is constrained by DE-PAL at level 1 , that is, its jurisdiction is limited to derived environments, as in bocz+ek, //bok $+\mathrm{EK} / / \rightarrow$ $/ b \mathrm{f}^{\mathrm{j}}+\mathrm{Ek} /$. It is imperative that morpheme-internal structure is not within the reach of PAL-Glide because morphemes such as kiep //kEp// 'fool' and cukier //tsukEr// 'sugar' must escape the $/ / \mathrm{k} / / \rightarrow / \mathrm{f}^{\mathrm{j}} /$ Palatalization and must emerge unscathed from level 1: $/ \mathrm{kEp} /$, not $* / \mathrm{f}^{\mathrm{j}} \mathrm{Ep} / \mathrm{and} / \mathrm{tsukEr} /$, not $* / \operatorname{tsut}{ }^{\mathrm{j}} \mathrm{Er} /$. At level 2, on the other hand, the objective is reversed: PAL-Glide must be able to look into morphemes: $/ \mathrm{kEp} / \rightarrow$ $/ \mathrm{k}^{\mathrm{j}} \mathrm{Ep} /$ and $/$ tsukEr/ $\rightarrow$ /tsuk $\mathrm{E} \mathrm{Er} /$.

The range of inputs to PAL-Glide is different at level 1 and level 2. At level 1, PALGlide affects not only //k g// but also //x//, as seen in (47): //bok+Ek// $\rightarrow / \mathrm{bot}{ }^{\mathrm{j}} \mathrm{Ek} /$ 'side' (dimin.) and //dax+Ek// $\rightarrow / \mathrm{da} \int^{\mathrm{j}} \mathrm{Ek} /$ 'roof' (dimin.). At level 2, PAL-Glide applies to //k g//, but not to //x//, as shown by cukier [tsuk ${ }^{\mathrm{j}} \mathrm{cr}$ ] 'sugar', with soft $\left[\mathrm{k}^{\mathrm{j}}\right.$ ] but wicher [ $\left.\mathrm{v}^{\mathrm{j}} \mathrm{ixer}\right]$ 'gale', with hard [x].

The activity of PAL- $e$ and PAL-Glide is different at different levels. PAL-e loses force at both the clitic phrase level (level 3) and the postlexical level (level 4). That is, the outputs are selected as optimal even if they violate PAL-e.

a. PAL-e at level 3: clitics

Tak powiedziat+em $[\mathrm{w}+\varepsilon \mathrm{m}]$ 'I said so' OR Tak+em [tak+em] powiedział 'So I said' (clitic movement)

prze $d+e$ gzaminacyjny $[\mathrm{d}+\varepsilon]$ 'pre-examination', not $*[\mathrm{~d}+\varepsilon]$ or $*\left[\mathrm{~d}^{\mathrm{j}}+\varepsilon\right]$ przed egzaminem $[\mathrm{d} \varepsilon]$ 'before the examination', not $*[\mathrm{~d}, \varepsilon]$ or $*\left[\mathrm{~d}^{\mathrm{j}}+\varepsilon\right]$, that is, no Palatalization of any kind

b. PAL-e at level 4: sentences

krok Ewy [krok $\varepsilon v \dot{i}]$ 'Eva's step', not *[krotf $\varepsilon v \dot{i}]$ or *[krok $\left.{ }^{j} \varepsilon v \dot{i}\right]$, that is, no Palatalization of any kind

The net result is that PAL-e produces no change at levels 3 and 4 . This means that the ranking of the constraints is different from that at level 2. Specifically, IDENT$\mathrm{C}[+\mathrm{back}]$ is now ranked above PAL-e.

$$
\begin{aligned}
& \text { Level 2: PAL- } e \gg \text { IDENT-C }[+ \text { back }]^{27} \\
& \text { Level } 3 \text { (and Level 4): IDENT-C }[+ \text { back }] \gg \text { PAL- } e
\end{aligned}
$$

In contrast to PAL-e, PAL-Glide is fully active at both level 3 and level 4.

\footnotetext{
${ }^{27}$ At level 2, IDENT-C [+back] is below both PAL- $e$ and PAL-Glide to enable them to derive $\left[\mathrm{k}^{\mathrm{j}}\right]$ in words such as krok+iem 'step' (instr.sg.) and kiep 'fool' (nom.sg.): $/ \mathrm{krok}+\varepsilon \mathrm{m} / \rightarrow\left[\mathrm{krok}^{\mathrm{j}} \mathrm{\varepsilon m}\right]$ and $/ \mathrm{kEp} / \rightarrow / \mathrm{k}^{\mathrm{j}} \mathrm{Ep} /$ (and further $\rightarrow\left[\mathrm{k}^{\mathrm{j}} \varepsilon \mathrm{p}\right]$ at level 3).
} 


a. PAL-Glide at level 3
prze $d+j$ edzeniowy $\left[\mathrm{d}^{\mathrm{j}}+\mathrm{j}\right]$ 'pre-eating',
przed jedzeniem $\left[\mathrm{d}^{\mathrm{j}}+\mathrm{j}\right]$ 'before eating'
$\operatorname{krok}$ jej $\left[\mathrm{k}^{\mathrm{j}} \mathrm{j}\right]$ 'her step'
duch jej $\left[\mathrm{x}^{\mathrm{j}} \mathrm{j}\right]$ 'her spirit'
brat $j \mathrm{jej}\left[\mathrm{t}^{\mathrm{j}} \mathrm{j}\right]$ 'her brother'
skecz jej $\left[\mathrm{t}^{\mathrm{j}} \mathrm{j}\right]$ 'her sketch'
sklep $j \operatorname{jej}\left[\mathrm{p}^{\mathrm{j}} \mathrm{j}\right]$ 'her store'

a. PAL-Glide at level 3

b. PAL-Glide at level 4 sklep Janka [ $\left.\mathrm{p}^{\mathrm{j}} \mathrm{j}\right]$ 'Janek's store' skecz Janka [ $\left.\mathrm{t}^{\mathrm{j}} \mathrm{j}\right]$ 'Janek's sketch' krok Janka [kj j] 'Janek's step' duch Janka [ $\left.\mathrm{x}^{\mathrm{j}} \mathrm{j}\right]$ 'Janek's spirit' brat Janka [ $\left.\mathrm{t}^{\mathrm{j}} \mathrm{j}\right]$ 'Janek's brother'

This is a very different situation from that found at level 2: PAL-Glide applies to all consonants in an unconstrained way. The generalization is captured by reranking PAL-Glide to an undominated position.

$$
\begin{aligned}
& \text { Level 2: } * \text { SOFT-Lab, } * \text { SOFT-Coron, } * \mathrm{x}^{\mathrm{j}} \gg \text { PAL-Glide } \gg \text { IDENT-C }[+ \text { back }] \\
& \text { Levels } 3 \text { and 4: PAL-Glide } \gg * \text { SOFT-Lab, } * \text { SOFT-Coron, }{ }^{*} \mathrm{x}^{\mathrm{j}} \text {, IDENT- } \\
& \text { C[+back] }
\end{aligned}
$$

To conclude, as (53) shows, a large number of segment inventory constraints determining admissible inventories are ranked differently in the word domain (level 2) and in the phrase domain (levels 3 and 4). The differences in ranking cannot be derived from Standard OT's opacity theories since these theories are not equipped to handle such differences. I conclude that the segment inventory constraints in (53) constitute an argument for levels and hence for Derivational OT.

In the following section, I look at PAL- $e$ from a historical perspective, focusing on $k g \rightarrow k^{j} g^{j}$, the effects of Surface Velar Palatalization.

\section{A historical perspective}

This section pursues the history of Surface Velar Palatalization from Old Polish (10th-15th c.), through Middle Polish (16th-18th c.) to Modern Polish (19th c. present). Of interest are the concatenations of $k, g$ and $e$, occurring inside morphemes and across morpheme boundaries.

Historical grammars of Polish concur: there was no Surface Velar Palatalization in Old Polish. Długosz-Kurczabowa and Dubisz (2006:147) cite zgietk 'turmoil' and kiełbasa 'sausage' as examples of words pronounced with hard [ke], [ge] in Old

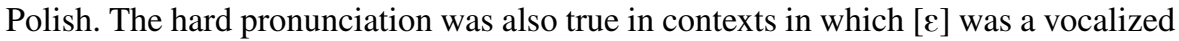
yer, as in the following examples (Długosz-Kurczabowa and Dubisz 2006:147).

$$
\begin{aligned}
& \text { kieł 'cuspid' (nom.sg.) - kł+y [nom.pl.), where kieł was pronounced [keł], } \\
& / / \mathrm{kEł} / /^{28} \rightarrow[\mathrm{k} \varepsilon ł] \text { by Yer Vocalization } \\
& \text { okn+o 'window'(nom.sg.) - okien (gen.pl.), where okien was pronounced } \\
& \text { [oken], //okEn// } \rightarrow \text { [oken] by Yer Vocalization } \\
& \text { ogień 'fire' - ogn+ie (nom.pl.), where ogień was pronounced [ogعn], } \\
& / / \mathrm{ogE} \mathrm{l} / / \rightarrow[\mathrm{og} \varepsilon \mathrm{p}] \text { by Yer Vocalization }
\end{aligned}
$$

\footnotetext{
${ }^{28}$ In Early Old Polish the nom.sg. and the gen.pl. had a back yer as an ending. Before the 11th century, the yer was a regular vowel, probably a high lax vowel. After the 11th c., yers either deleted or lowered to [ $\varepsilon$ ]. I sidestep the issue of how inflectional yers should be analyzed in Old Polish.
} 
The absence of Surface Velar Palatalization morpheme-internally raises the question of whether the process might have been limited to derived environments, which would explain its absence morpheme-internally. Limitation to derived environments is commonplace in Slavic phonology (see Rubach 1984). The answer is negative: Surface Velar Palatalization did not apply in derived environments. This is the conclusion of Stieber (1973:67-68), who evaluated scribal practices in Old Polish.

$$
\begin{aligned}
& \text { język 'tongue' (nom.sg.) - język+em [k+عm] (instr.sg.) }
\end{aligned}
$$

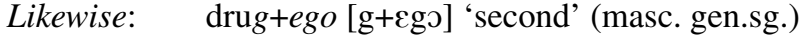

$$
\begin{aligned}
& \text { nyebyesk+emu [k+emu] 'blue'(masc. dat.sg.) } \\
& \text { słod } k+e y[\mathrm{k}+\varepsilon j] \text { 'sweet' (fem. gen.sg.) } \\
& \text { wisso } k+e[\mathrm{k}+\varepsilon] \text { 'tall' (fem./neuter nom.pl.) }
\end{aligned}
$$

The generalization is clear: $\left[\mathrm{k}^{\mathrm{j}} \mathrm{g}^{\mathrm{j}}\right]$ did not exist as phonetic segments in Old Polish. ${ }^{29}$ The absence of $\left[\mathrm{k}^{\mathrm{j}} \mathrm{g}^{\mathrm{j}}\right]$ means that the segment inventory constraints $* k^{j}$, $* g^{j}$ were undominated and blocked Palatalization from all PAL constraints.

According to Stieber (1973) and Długosz-Kurbaczowa and Dubisz (2006), this situation changed in Early Middle Polish (16th c.): soft $\left[\mathrm{k}^{\mathrm{j}} \mathrm{g}^{\mathrm{j}}\right]$ started occurring in the very same contexts in which there were hard $[\mathrm{kg}]$ in Old Polish, so the examples in (55) would now look as follows.

$$
\begin{aligned}
& \text { język 'tongue' (nom.sg.) - język+iem }\left[\mathrm{k}^{\mathrm{j}}+\varepsilon \mathrm{m}\right] \text { (instr.sg.) }{ }^{30} \\
& \text { Likewise: } \quad \text { drug+iego }\left[\mathrm{g}^{\mathrm{j}}+\varepsilon \mathrm{g} \rho\right] \text { 'second' (masc. gen.sg.) } \\
& \text { niebiesk+iemu }\left[\mathrm{k}^{\mathrm{j}}+\varepsilon \mathrm{mu}\right] \text { 'blue' (masc. dat.sg.) } \\
& \text { słod } k+i e j\left[\mathrm{k}^{\mathrm{j}}+\varepsilon \mathrm{j}\right] \text { 'sweet' (fem. gen.sg.) } \\
& \text { wysok }+i e\left[\mathrm{k}^{\mathrm{j}}+\varepsilon\right] \text { 'tall' (fem./neuter nom.pl.) }
\end{aligned}
$$

Surface Velar Palatalization applied not only at morpheme boundaries (56) but also morpheme-internally.

$\begin{array}{lll}\text { Old Polish } & \text { Middle Polish } & \\ {[\mathrm{k} \varepsilon \mathrm{di}]} & {\left[\mathrm{k}^{\mathrm{j}} \varepsilon \mathrm{di}\right]} & \text { kiedy 'when' } \\ {[\mathrm{zg} \varepsilon \nmid \mathrm{k}]} & {\left[\mathrm{zg}^{\mathrm{j}} \varepsilon \nmid \mathrm{k}\right]} & \text { zgiełk 'turmoil' } \\ {[\mathrm{k} \varepsilon ł b a s a]} & {\left[\mathrm{k}^{\mathrm{j}} \varepsilon ł b a s a\right]} & \text { kiełbasa 'sausage' } \\ {[\mathrm{k} \varepsilon \mathrm{f}]} & {\left[\mathrm{k}^{\mathrm{j}} \varepsilon ł\right]} & \text { kiet 'cuspid' } \\ {[\mathrm{g} \varepsilon \mathrm{z}]} & {\left[\mathrm{g}^{\mathrm{j}} \varepsilon \mathrm{s}\right]} & \text { giez 'gadfly' }\end{array}$

In terms of the constraint system, the change between Old Polish and Middle Polish is a matter of reranking of the segment inventory constraints $* k^{j} * g^{j}$.

$$
\begin{array}{ll}
\text { Old Polish: } & * \mathrm{k}^{\mathrm{j}} * \mathrm{~g}^{\mathrm{j}} \gg \text { PAL-e } \\
\text { Middle Polish: } & \text { PAL-e } \gg * \mathrm{k}^{\mathrm{j}} * \mathrm{~g}^{\mathrm{j}}
\end{array}
$$

The word kiedy 'when' serves as an example illustrating the changes.

\footnotetext{
${ }^{29}$ This is generally true, not only for the $\left[\mathrm{k}^{\mathrm{j}} \mathrm{g}^{\mathrm{j}}\right]$ that would have been derived in the context of $e$. The other potential source of phonetic $\left[\mathrm{k}^{\mathrm{j}} \mathrm{g}^{\mathrm{j}}\right]$ would be PAL-i, but until the 16 th $\mathrm{c}$. [k g] could not be followed by [i], for example, today's $g i b k+i\left[\mathrm{~g}_{\mathrm{i}} \mathrm{ipk}_{\mathrm{i}} \mathrm{j}_{\text {] }}\right.$ 'bending' was $g y b k+y$ [gipki]; see Stieber (1973) for discussion.

${ }^{30}$ The examples here and in (57) below are cited from Stieber (1973:67-68) and Długosz-Kurbaczowa and Dubisz (2006:146).
} 
i. Old Polish $/ \mathrm{k} \varepsilon \mathrm{di} /=[\mathrm{kedi}]$ (no change)

\begin{tabular}{|c|c|c|c|}
\hline & $* \mathrm{k}^{\mathrm{j}}{ }^{*} \mathrm{~g}^{\mathrm{j}}$ & PAL-e & IDENT-C[+back] \\
\hline a. kedi & & $*$ & \\
\hline b. $\mathrm{k}^{\mathrm{j}} \varepsilon \mathrm{di}$ & $* !$ & & $*$ \\
\hline
\end{tabular}

ii. Middle Polish $/ \mathrm{k} \varepsilon \mathrm{di} / \rightarrow\left[\mathrm{k}^{\mathrm{j}} \varepsilon \mathrm{di}\right]$ (Surface Velar Palatalization)

\begin{tabular}{|r|c|c|c|}
\hline & PAL-e & $* \mathrm{k}^{\mathrm{j}}{ }^{*} \mathrm{~g}^{\mathrm{j}}$ & IDENT-C[+back] \\
\hline a. $\mathrm{k} \varepsilon \mathrm{di}$ & $* !$ & & I \\
\hline b. $\mathrm{k}^{\mathrm{j}} \varepsilon \mathrm{di}$ & & $*$ & $*$ \\
\hline
\end{tabular}

Surface Velar Palatalization was perfectly productive in Middle Polish and it applied to all borrowings whose input structure had $[\mathrm{k} \varepsilon]$ or $[\mathrm{g} \varepsilon]$. A sample of representative examples are cited from Sławski (1952).

(60) kies+a, [ $\left.\mathrm{k}^{\mathrm{j}} \varepsilon \mathrm{sa}\right]$ 'purse', a 17th c. borrowing from Turkish kese kieln+ia [kj $\left.\mathrm{k}^{\mathrm{j}} \mathrm{lna}\right]$ 'trowel', a 16th c. borowing from German Kelle kaszkiet [kafk $\left.\mathrm{k}^{\mathrm{c}} \mathrm{t}\right]$ 'cap', an 18th c. borrowing from French casquette giemz+a [g $\left.{ }^{\mathrm{j}} \mathrm{cmza}\right]$ 'chamois', a 16th c. borrowing from German Gemse giermek [ $\left.\mathrm{g}^{\mathrm{j}} \mathrm{ermek}\right]$ 'page', a 15th c. borrowing from Hungarian gyermek

The 18th and the 19th centuries witnessed a huge influx of borrowings and the pronunciation of the foreign [kgge] was much debated in the linguistic literature of the 19th century. For example, Jeske (1800) states explicitly that the soft pronunciation $\left[\mathrm{g}^{\mathrm{j}} \varepsilon\right]$ is used in gest $\left[\mathrm{g}^{\mathrm{j}} \varepsilon \mathrm{st}\right]$ 'gesture', geologia $\left[\mathrm{g}^{\mathrm{j}} \varepsilon \log ^{\mathrm{j}} \mathrm{ja}\right.$ ] 'geology', ge-

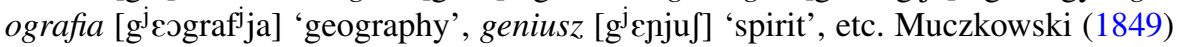
establishes a rule that prohibits hard $g$ before $e$. Małecki (1863) concurs that $g$ is always pronounced soft before $e$, as in tragedia [trag ${ }^{\mathrm{j}} \varepsilon \mathrm{d}^{\mathrm{j}} \mathrm{ja}$ ] 'tragedy', algebra

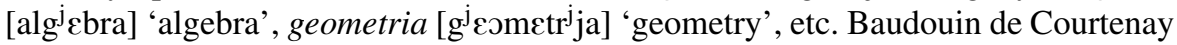
et al. (1899) record soft $\left[\mathrm{g}^{\mathrm{j}} \varepsilon\right]$ in, for instance, legenda [leg $\left.{ }^{\mathrm{j}} \varepsilon \mathrm{nda}\right]$ 'legend', gestyku-

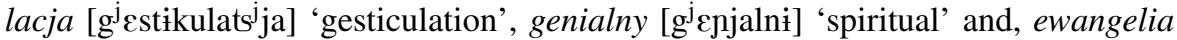
[عvang ${ }^{j} \varepsilon^{\mathrm{j}} \mathrm{ja}$ ] 'gospel'. Kryński (1903:308) agrees with the rule $k g \rightarrow k^{j} g^{j}$ before $e$ and adds new examples: ankieta [ayk $\mathrm{k}^{\mathrm{j}} \varepsilon \mathrm{ta}$ ] 'inquiry', agenda $\left[\mathrm{ag}^{\mathrm{j}} \mathrm{cnda}\right.$ ' $a g e n c y$ ' and bukiet [buk $\left.\mathrm{k}^{\mathrm{j}} \mathrm{t}\right]$ 'bouquet'. He adopts the spelling convention that soft $\left[\mathrm{k}^{\mathrm{j}} \mathrm{g}^{\mathrm{j}}\right]$ are marked by the letter $i$ that is not pronounced. This leads him to recommend, for example, the following spellings.

\begin{tabular}{|c|c|c|}
\hline Kryński's spelling (1903:308) & today's spelling & gloss \\
\hline legienda $\left[1 \varepsilon^{\mathrm{j}} \varepsilon n d a\right]$ & legenda & 'legend' \\
\hline agienda $\left[\mathrm{ag}^{\mathrm{j}} \varepsilon \mathrm{nda}\right]$ & agenda & 'agency' \\
\hline algiebra $\left[\right.$ alg ${ }^{\mathrm{j}} \varepsilon$ bra] & algebra & 'algebra' \\
\hline ewangielja [cvang $\left.{ }^{\mathrm{j}} \varepsilon^{\mathrm{j}} \mathrm{ja}\right]$ & ewangelia & 'gospel' \\
\hline gienerał $\left[\mathrm{g}^{\mathrm{j}}\right.$ enerał] & generał & 'general' \\
\hline giest $\left[\mathrm{g}^{\mathrm{j}} \varepsilon \mathrm{st}\right]$ & gest & 'gesture' \\
\hline
\end{tabular}

Finally, Ładoń (1920:10) mandates that " $k, g$ before $e$ or $i$ must be pronounced soft as kie, gie" ${ }^{31}$ [my translation: IR], for instance, kiefir $\left[\mathrm{k}^{\mathrm{j}} c \mathrm{f}^{\mathrm{j}} \mathrm{ir}\right]$ 'kefir', kierat $\left[\mathrm{k}^{\mathrm{j}} \varepsilon \mathrm{rat}\right]$

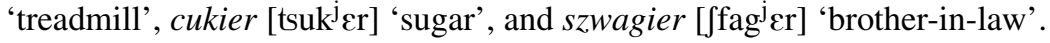

${ }^{31}$ The spellings kie and gie denote the pronunciation $\left[\mathrm{k}^{\mathrm{j}} \varepsilon\right]$ and $\left[\mathrm{g}^{\mathrm{j}} \varepsilon\right]$, respectively. 
The pronunciation of the foreign $[\mathrm{k} \varepsilon \mathrm{g \varepsilon}]$ as $\left[\mathrm{k}^{\mathrm{j}} \varepsilon \mathrm{g}^{\mathrm{j}} \varepsilon\right]$ shows that PAL-e applies productively not only at morpheme boundaries, as in krok+iem 'step' (instr. sg.) and rog+iem 'horn' (instr. sg.) but also inside morphemes. To achieve this result, PAL-e must outrank DE-PAL, so that the derived environment restriction has no force. ${ }^{32}$

The situation just described changes in the middle of the 20th century. First, new borrowings are not assimilated by palatalizing $k, g$ before $e$. Second, we witness pronunciation reversals on a huge scale.

\begin{tabular}{|c|c|c|}
\hline \multicolumn{3}{|c|}{ New borrowings (later than 1950) } \\
\hline a. hard $[\mathrm{k} \varepsilon]$ : & dysk dżokej ‘disc jockey’ & keczup 'ketchup' \\
\hline \multirow{5}{*}{ b. hard $[\mathrm{ge}]$} & marker 'marker' & marketing 'marketing' \\
\hline & karaoke 'karaoke' & kebab 'type of hamburger' \\
\hline & gem 'game' & genetyk+a 'genetics' \\
\hline & gen 'gene' & geriatria 'geriatrics' \\
\hline & hamburger 'hambur & getry 'long socks' \\
\hline
\end{tabular}

The generalization is that PAL-e stopped applying morpheme-internally. Palatalization is still $100 \%$ productive at morpheme boundaries, as shown by the fact that it applies to foreign names.

$$
\begin{aligned}
& \text { Edynburg 'Edinburgh' - Edenburg+iem }\left[\mathrm{g}^{\mathrm{j}}+\varepsilon \mathrm{m}\right] \text { (instr.sg.) } \\
& \text { Sherlock Holmes - Sherlock+iem }\left[\mathrm{k}^{\mathrm{j}}+\varepsilon \mathrm{m}\right] \text { Holmsem (instr.sg.) }
\end{aligned}
$$

The limitation of PAL- $e$ to derived environments induces restructuring of underlying representations, as the following examples show. ${ }^{33}$

$$
\begin{aligned}
& \text { kiedy } / / \mathrm{ked} \mathfrak{i} / / \text { is restructured as } / / \mathrm{k}^{\mathrm{j}} \varepsilon \mathrm{di} / / \\
& \text { Likewise: } \quad \text { kier+owa+ć } / / \mathrm{ker} / / \rightarrow / / \mathrm{k}^{\mathrm{j}} \mathrm{cr} / / \text { 'move in a direction' } \\
& \text { pakiet //paket// } \rightarrow / / \text { pakj }^{\mathrm{j}} \mathrm{ct} / / \text { 'packet' } \\
& \text { giermek //germek// } \rightarrow / / \mathrm{g}^{\mathrm{j}} \text { crmek// 'page' } \\
& \text { giemz+a //gemz+a// } \rightarrow / / \mathrm{g}^{\mathrm{j}} \mathrm{emz}+\mathrm{a} / / \text { 'chamois' } \\
& \text { higien+a //xigen+a// } \rightarrow / / x^{i g}{ }^{j} \varepsilon n+a / / \text { 'hygiene' }
\end{aligned}
$$

The representations restructure by moving the previously derivable $\left[\mathrm{k}^{\mathrm{j}} \varepsilon \mathrm{g}^{\mathrm{j}} \varepsilon\right]$ to the underlying representation. The reason is that PAL- $e$, now constrained by DE-PAL, cannot derive morpheme-internal $\left[\mathrm{k}^{\mathrm{j}} \mathrm{g}^{\mathrm{j}}\right]$ any longer.

In contrast, the $\left[\mathrm{k}^{\mathrm{j}} \mathrm{g}^{\mathrm{j}}\right]$ derivable by PAL-Glide do not restructure as $/ / \mathrm{k}^{\mathrm{j}} \mathrm{g}^{\mathrm{j}} / /$. The vowel is a yer, as shown by the fact that we have an $e$-zero alternation.

$\begin{array}{llll}\text { nom.sg. } & \text { gen.sg. } & \text { UR } & \text { gloss } \\ {\left[\mathrm{k}^{\mathrm{j}} \varepsilon \mathrm{p}\right]} & \mathrm{kp}+\mathrm{a}[\mathrm{kpa}] & / / \mathrm{kEp} / / & \text { 'fool' } \\ \left.\text { lukier [luk } \mathrm{k}^{\mathrm{j}} \varepsilon \mathrm{r}\right] & \text { lukr+u [lukru] } & / / \mathrm{lukEr} / / & \text { 'frosting' } \\ \text { ogień }\left[\mathrm{og}^{\mathrm{j}} \varepsilon \mathrm{c}\right] & \text { ogn+ia [ogna] } & / / \mathrm{ogEn} / / & \text { 'fire' }\end{array}$

\footnotetext{
${ }^{32}$ This was true for level 2. At level 1, PAL-e and PAL-Glide were restricted to derived environments already in Old Polish and this restriction has never been lifted.

${ }^{33}$ It is not clear when the restructuring occurred, but it is only now when PAL-e cannot apply morphemeinternally that the restructuring becomes evident.
} 
As noted in (44) in Sect. 3, Palatalization before $E$ is $100 \%$ reliable and exceptionless. The underlying representation is therefore underspecified for the predictable [-back] feature on the velar consonant.

The historical level 2 reranking of PAL- $e \gg$ DE-PAL to DE-PAL $\gg$ PAL- $e$ and hence the inability of producing Palatalization morpheme-internally has resulted in massive pronunciation reversals. The very same examples that the 19th c. grammarians used in order to illustrate the pronunciation $\left[\mathrm{k}^{\mathrm{j}} \varepsilon \mathrm{g}^{\mathrm{j}} \varepsilon\right]$ are now examples for hard [ke ge].

\begin{tabular}{|c|c|c|}
\hline \multicolumn{3}{|c|}{ Pronunciation reversals } \\
\hline 19 th $c$. & today & gloss \\
\hline$\left[\mathrm{k}^{\mathrm{j}} \varepsilon \mathrm{f}^{\mathrm{j}} \mathrm{ir}\right]$ & {$\left[\mathrm{kef}^{\mathrm{j}} \mathrm{ir}\right]$} & kefir 'kefir' \\
\hline$\left[\mathrm{k}^{\mathrm{j}} \varepsilon \ln \varepsilon \mathrm{r}\right]$ & [kelner] & kelner 'waiter' \\
\hline$\left[1 \varepsilon g^{\mathrm{j}} \varepsilon \mathrm{nda}\right]$ & [legenda] & legenda 'legend' \\
\hline$\left[\mathrm{g}^{\mathrm{j}} \varepsilon \mathrm{st}\right]$ & [gest] & gest 'gesture' \\
\hline$\left[\mathrm{g}^{\mathrm{j}} \varepsilon n \varepsilon r a ł\right]$ & [generaw] & generat 'general' \\
\hline 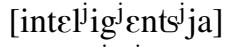 & [inte $\mathrm{l}^{\mathrm{j}}{ }_{\text {igents }}^{\mathrm{j}} \mathrm{ja}$ ] & inteligencja 'intelligence' \\
\hline$\left[\varepsilon \operatorname{vang}{ }^{\mathrm{j}} \varepsilon \mathrm{l}^{\mathrm{j}} \mathrm{ja}\right]$ & {$\left[\varepsilon \operatorname{vang} \varepsilon^{\mathrm{j}} \mathrm{ja}\right]$} & ewangelia 'gospel' \\
\hline
\end{tabular}

The words in (66), for example, legend $+a$ 'legend', illustrate Duke-of-York derivations (Pullum 1976), but in a diachronic rather than synchronic dimension. Sławski (1952) states that legenda is a 16th c. borrowing of the mediaeval Latin legenda 'story of saints'. At the point of borrowing, the ge in legenda was pronounced [ge]. In 1903 exactly this word is cited by Kryński (1903) as an example of the soft $\left[\mathrm{g}^{\mathrm{j}} \varepsilon\right]$ pronunciation. Today legenda is invariably pronounced with hard $[\mathrm{g} \varepsilon]$. Schematically:

$$
\begin{array}{llll}
\text { 16th } c . & 16-19 \text { th } c . & \text { today } & \text { gloss } \\
\text { [legenda] } & {\left[\operatorname{lig}^{\mathrm{j}} \varepsilon \text { enda }\right]^{34}} & \text { [legenda }] & \text { 'legend' }
\end{array}
$$

Pronunciation reversals do not constitute a problem for a theory that distinguishes between underlying and surface representations. Looking at legenda as an example, the Latin legenda enters Polish with //ge// because [ge] is the surface representation in the 16th c., [legend+a] = //legend $+\mathrm{a} / /$. The pronunciation $\left[1 \mathrm{\varepsilon g}^{\mathrm{j}} \varepsilon \mathrm{knda}\right]$ is an effect of Surface Velar Palatalization, a rule that develops in the 16th/17th c. Since the derivation $g \rightarrow g^{j}$ is fully predictable from Surface Velar Palatalization, the underlying representation is underspecified for Palatalization, //legend+a//. In the 20th c. Surface Velar Palatalization changes status and becomes restricted to derived environments. Consequently, it can no longer affect morpheme-internal //ge// and hence legenda starts surfacing as [legenda], with hard [ge]. Some words such as giermek $\left[\mathrm{g}^{\mathrm{j}} \mathrm{crmek}\right.$ ] 'page' and kiedy $\left[\mathrm{k}^{\mathrm{j}} \varepsilon \mathrm{di}\right]$ 'when' restructured their underlying representations from $/ / \mathrm{g} \varepsilon / /$ and $/ \mathrm{k} \varepsilon / /$ to $/ / \mathrm{g}^{\mathrm{j}} \varepsilon / /$ and $/ / \mathrm{k}^{\mathrm{j}} \varepsilon / /$, respectively, because there were no alternations between $\left[\mathrm{k}^{\mathrm{j}} \mathrm{g}^{\mathrm{j}}\right]$ and $[\mathrm{kg}]$. The restructuring process was lexically diffused and proceeded in an item-by-item manner, so, for example, the restructuring occurred in gier$m e k / / \mathrm{g}^{\mathrm{j}} \mathrm{rrm} \varepsilon \mathrm{k} / /$ 'page' but not in legenda //legend+a// 'legend'. When, in the 20th c.,

\footnotetext{
${ }^{34}$ It is difficult to establish at which point exactly the $\left[\mathrm{g}^{\mathrm{j}} \varepsilon\right]$ pronunciation started occurring. What we know as a fact is that in $1903\left[\mathrm{~g}_{\varepsilon}^{\mathrm{j}}\right]$ was attested. Most probably, the $\left[\mathrm{g}_{\varepsilon} \mathrm{j}_{\varepsilon}\right]$ pronunciation existed already in the 16 th/17th c. because this is the time when Surface Velar Palatalization entered Polish as a rule.
} 
Surface Velar Palatalization lost jurisdiction over morpheme-internal structures, underlying representations emerged as surface representations, yielding $\left[\mathrm{g}^{\mathrm{j}} \varepsilon \mathrm{rm} \varepsilon \mathrm{k}\right]$ and [legenda], respectively.

These pronunciation reversals highlight a new theoretical point. Namely, they show that reversals are possible in the absence of alternations. Kiparsky's (1973) conclusion that reversals may occur only in instances of alternation is therefore too restrictive. $^{35}$

The story of ke, ge is relevant for the understanding of the life cycle of a process (Baudouin de Courtenay 1894; Hyman 1976; Bermúdez-Otero 1999, 2007, 2013; Kiparsky 2013). The idea of the life cycle is that a phonological process starts in phonetics and, when phonologized, begins to climb up the strata of Derivational/Stratal OT, beginning with the postlexical stratum (Bermúdez-Otero 2013). At late stages in the life cycle, the process is morphologized, stops being productive and finally expires. The story of $k e$, ge makes two additions to this understanding of the life cycle. First, a process may begin at level 2 rather than at level $4 .{ }^{36}$ Second, evolution of a process goes through the stage at which it develops a DE restriction. At that stage, the process is still extremely regular and exceptionless, as exemplified by Surface Velar Palatalization, but its jurisdiction has narrowed down to derived environments.

A further point that the story of ke, ge brings out is the characterization of Palatalization in terms of PAL constraints. The DE restriction has affected PAL- $e$ but not PAL-Glide and PAL- $i$ (see the Appendix below), which continue to apply morphemeinternally as in $/ / \mathrm{kEp} / / \rightarrow / \mathrm{k}^{\mathrm{j}} \mathrm{Ep} /$ 'fool' (and $/ \mathrm{k}^{\mathrm{j}} \mathrm{Ep} / \rightarrow\left[\mathrm{k}^{\mathrm{j}} \varepsilon \mathrm{p}\right]$ at level 3), //dialekt $/ / \rightarrow$ [d $\mathrm{d}^{\mathrm{j} j a l \varepsilon k t] ~ ' d i a l e c t ' . ~ T h i s ~ d i f f e r e n c e ~ i n ~ t h e ~ b e h a v i o r ~ o f ~ P A L-e ~ a n d ~ P A L-G l i d e ~(a s ~ w e l l ~}$ as PAL- $i$ ) shows that PAL-e is an independent generalization that should not be collapsed with the other PAL constraints.

Finally, the development of $/ / \mathrm{k}^{\mathrm{j}} \mathrm{g}^{\mathrm{j}} / /$ as underlying segments is an example of phonologization in the sense of Kiparsky (2013). The observation is that secondary split is effected here not through the destruction of the environment but through the change of status of the process from across-the-board-application to derived environments.

\section{Summary of interactions}

This section summarizes the interaction of the constraints and compares their ranking at different levels. Before summarizing the ranking, I illustrate schematically the changes at a given level by looking at the alteration of segments in four relevant

\footnotetext{
${ }^{35}$ Kiparsky $(1968,1973)$ has argued that the loss of Final Devoicing in Yiddish resulted in the pronunciation of the morpheme weg 'away' as [vek] but the morpheme Weg 'way' as [veg]. The difference is ascribed to the fact that weg [vek] 'away' never had any alternant with [g] while Weg [vek] 'way' had the allomorph [veg] occurring in inflected forms such as Weg+e [veg+ə] (pl.), so in the noun there was an alternation between $[\mathrm{k}]$ and $[\mathrm{g}]$.

${ }^{36}$ Evidence for postlexical processes is notoriously difficult to find in historical phonology, but some insight can be gleaned from the inspection of modern languages. As far as I know, no Slavic language has Palatalization before $e$ across word boundaries. This is true also for Russian that in general has robust Palatalization triggered by $e$ in derived and non-derived environments.
} 
contexts: before //ع// and before //E//, across morpheme boundaries and inside morphemes. I look at velars (represented by $k$ ), coronals (represented by $t$ ) and labials (represented by $p$ ).

(68) Level 1

\begin{tabular}{|l|l|l|l|l|l|l|l|l|l|l|l|l|}
\hline input & $\mathrm{k}+\varepsilon$ & $\mathrm{t}+\varepsilon$ & $\mathrm{p}+\varepsilon$ & $\mathrm{k}+\mathrm{E}$ & $\mathrm{t}+\mathrm{E}$ & $\mathrm{p}+\mathrm{E}$ & $\mathrm{k} \varepsilon$ & $\mathrm{t} \varepsilon$ & $\mathrm{p} \varepsilon$ & $\mathrm{kE}$ & $\mathrm{tE}$ & $\mathrm{pE}$ \\
\hline output & $\mathrm{f}^{\mathrm{j}}+\varepsilon$ & $\mathrm{t}^{\mathrm{j}}+\varepsilon$ & $\mathrm{p}^{\mathrm{j}}+\varepsilon$ & $\mathrm{t}^{\mathrm{j}}+\mathrm{E}$ & $\mathrm{t}^{\mathrm{j}}+\mathrm{E}$ & $\mathrm{p}^{\mathrm{j}}+\mathrm{E}$ & $\mathrm{k} \varepsilon$ & $\mathrm{t} \varepsilon$ & $\mathrm{p} \varepsilon$ & $\mathrm{kE}$ & $\mathrm{tE}$ & $\mathrm{pE}$ \\
\hline
\end{tabular}

Phonemic Velar Palatalization, $\mathrm{k} \rightarrow \mathrm{t}^{\mathrm{j}}$, is executed by ranking IDENT-Dor low and ${ }^{*} k^{j},{ }^{*} g^{j},{ }^{*} x^{j}$ high, so that velars have to change into coronals. The output must be a [-anter] affricate, which is enforced by POSTER (13) and STRID (14). The details of the ranking are as follows.

Level 1 ranking

IDENT-C[-back] $\gg * \mathrm{k}^{\mathrm{j}} * \mathrm{~g}^{\mathrm{j}} * \mathrm{x}^{\mathrm{j}}$, IDENT-V[-back], DE-PAL $\gg$ PAL-e, PALGlide $\gg$ IDENT-C[+back], *SOFT-Coron, *SOFT-Lab, IDENT[+anter], IDENT[-strid] $\gg$ POSTER, STRID, HARD, IDENT-Dor, $* \mathrm{t}_{6} \gg * \mathrm{f}^{\mathrm{j}}$

IDENT-C [-back] is undominated at level 1 because neither hardening nor loss of underlying [-back] on soft consonants is admissible. Importantly, IDENT-C[-back] 》 $* k^{j} * g^{j} * x^{j}$ makes sure that underlying soft velars, as in kiedy $/ / \mathrm{k}^{j} \varepsilon \mathrm{di} / /$ ' when', sail unscathed through level 1 . The ranking IDENT-V[-back] $\gg$ IDENT-C [+back], *SOFTCoron, *SOFT-Lab guarantees that Palatalization of hard consonants rather than Retraction of front vowels is the response to PAL constraints at level 1. PAL-e and PALGlide palatalize not only velars but also coronals and labials, so PAL-e, PAL-Glide $\gg *$ SOFT-Coron, *SOFT-Lab. Palatalization is limited to derived environments, hence DE-PAL $\gg$ PAL-e, PAL-Glide. Velars //k g x// palatalize to soft postalveo-

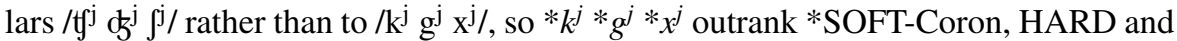
IDENT-Dor. Dentals //t d s z// go to $/ \mathrm{t}^{\mathrm{j}} \mathrm{d}^{\mathrm{j}} \mathrm{s}^{\mathrm{j}} \mathrm{z}^{\mathrm{j}} /$ at level 1, so IDENT[+anter], IDENT[strid] dominate POSTER and STRID. The outputs of PhonemicVelar Palatalization are the postalveolars $/ \mathrm{t}^{\mathrm{j}} \mathrm{c}^{\mathrm{j}} \mathrm{j}^{\mathrm{j}} /$ rather than the prepalatals $/ \mathrm{t}_{6} \mathrm{~d} / 6 \mathrm{z} /$, which means that the constraint against the latter is ranked above the constraint against the former: ${ }^{*} t_{6}$ $\gg * t^{j}$.

Level 2 segmental changes do not include palatalized labials because $\left[p^{\mathrm{j}}+\varepsilon\right]$ derived at level 1 is the final output. Morpheme-internal [pe] is also the attested surface form. The inputs with yers, for instance, $/ \mathrm{p}^{\mathrm{j}}+\mathrm{E} /$ either delete the yer (when $/ \mathrm{E} /$ is followed by a consonant and a full vowel) or leave the /E/ intact, so that it can vocalize at level 3: $E \rightarrow \varepsilon$.

Level 2
\begin{tabular}{|l|l|l|l|l|l|l|l|l|l|}
\hline input & $\mathrm{t}^{\mathrm{j}}+\varepsilon$ & $\mathrm{t}^{\mathrm{j}}+\varepsilon$ & $\mathrm{t}^{\mathrm{j}}+\mathrm{E}$ & $\mathrm{t}^{\mathrm{j}}+\mathrm{E}$ & $\mathrm{k}+\varepsilon^{37}$ & $\mathrm{k} \varepsilon$ & $\mathrm{t} \varepsilon$ & $\mathrm{kE}$ & $\mathrm{tE}$ \\
\hline output & $\mathrm{f}+\varepsilon$ & $\mathrm{t} 6+\varepsilon$ & $\mathrm{f}+\mathrm{E}$ & $\mathrm{t} 6+\mathrm{E}$ & $\mathrm{k}^{\mathrm{j}}+\varepsilon$ & $\mathrm{k} \varepsilon$ & $\mathrm{t} \varepsilon$ & $\mathrm{k}^{\mathrm{j}} \mathrm{E}$ & $\mathrm{tE}$ \\
\hline
\end{tabular}

Level 2 witnesses Hardening, $t^{j} \rightarrow t$, so HARD is reranked to an undominated position. Velars palatalize in a surface manner, $k \rightarrow k^{j}$, before level 2 suffixes, so in DE contexts. The yer /E/, effects $k \rightarrow k^{j}$ in non-DE environments, so morphemeinternally. The absence of $k \rightarrow t^{j}$ is accounted for by reranking IDENT-Dor to

${ }^{37}$ The $/ \varepsilon /$ is part of a level 2 suffix. 
an undominated position. Finally, palatalized coronals are spelled out as prepalatals, $t^{j} \rightarrow t_{6}$. The details are as follows.

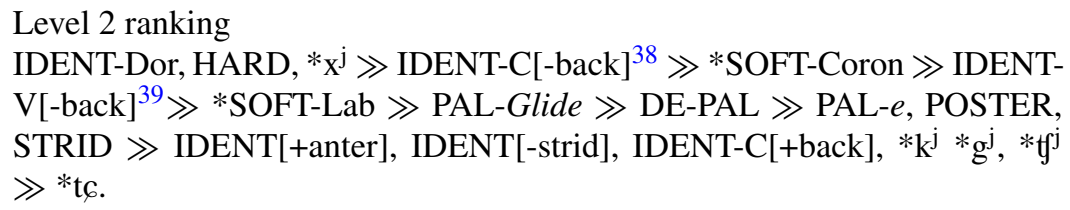
$\mathrm{V}[\text {-back }]^{39} \gg *$ SOFT-Lab $\gg$ PAL-Glide $\gg$ DE-PAL $\gg$ PAL-e, POSTER, STRID $\gg$ IDENT[+anter], IDENT[-strid], IDENT-C[+back], $* k^{j} * \mathrm{~g}^{\mathrm{j}}, *^{\mathrm{j}}$ $\gg * t_{6}$.

As noted, level 2 exhibits some dramatic changes. First, Phonemic Velar Palatalization is closed as an option, so IDENT-Dor is reranked to an undominated position. PAL- $e$ and PAL-Glide palatalize velar stops in a surface manner, $/ \mathrm{k} \mathrm{g} / \rightarrow\left[\mathrm{k}^{\mathrm{j}} \mathrm{g}^{\mathrm{j}}\right]$, but the velar fricative / $\mathrm{x} /$ does not palatalize at all, so $* k^{j} * g^{j}$, but not $* x^{j}$, are bottomranked at level 2. HARD, inducing $/ \mathrm{f}^{\mathrm{j}} \mathrm{d}^{\mathrm{j}} \mathrm{j}^{\mathrm{j}} \mathrm{f} \rightarrow\left[\mathrm{t} \mathrm{g} \mathrm{d} \int\right]$, is obeyed without exception, so HARD is reranked to an undominated position, crucially, above IDENT-C[-back]. IDENT-C[-back] yields to HARD but not to *SOFT-Coron, *SOFT-Lab and, therefore, it continues to outrank these constraints. PAL-Glide is no longer limited to derived environments and applies morpheme-internally, as in $/ \mathrm{kEp} / \rightarrow / \mathrm{k}^{\mathrm{j}} \mathrm{Ep} /$ 'fool'. Consequently, PAL-Glide is reranked above DE-PAL. To induce $/ \mathrm{k} \mathrm{g} / \rightarrow\left[\mathrm{k}^{\mathrm{j}} \mathrm{g}^{\mathrm{j}}\right]$, PALGlide must outrank $* k^{j} * g^{j}$. PAL-e and PAL-Glide affect velars, $/ \mathrm{k} \mathrm{g} / \rightarrow\left[\mathrm{k}^{\mathrm{j}} \mathrm{g}^{\mathrm{j}}\right]$, but not coronals or labials, so *SOFT-Coron, *SOFT-Lab $\gg$ PAL-e, PAL-Glide. Since input soft coronals and labials do not lose their [-back] property, IDENT-C[-back] must continue outranking *SOFT-Coron, *SOFT-Lab. The enhancement spell-out operation $/ \mathrm{t}^{\mathrm{j}} \mathrm{d}^{\mathrm{j}} \mathrm{s}^{\mathrm{j}} \mathrm{z}^{\mathrm{j}} / \rightarrow\left[\mathrm{t}_{6} \mathrm{~d}_{\mathrm{C}} \mathrm{c}_{\mathrm{z}}\right]$ is effected at level 2, hence the grip of IDENT[+anter] and IDENT[-strid] must be released by reranking POSTER and STRID above these faithfulness constraints. The spell-out produces prepalatals $\left[\begin{array}{llll}t_{6} & \& & 6 & \zeta\end{array}\right]$ rather than postalveolars $\left[\mathrm{tg}^{\mathrm{j}} \mathrm{d}^{\mathrm{j}} \int^{\mathrm{j}} 3^{\mathrm{j}}\right.$ ], so the level 1 ranking $* t c \gg * t^{j}$ is reversed at level 2 : * $\mathrm{f}^{j}$ $\gg * t 6$.

Level 3 segmental changes are all allophonic and occur before the glide $[\mathrm{j}]^{40}$ since the yer (the glide /E/) now vocalizes as a full vowel $[\varepsilon]$, so it is no longer a glide.

Level 2
\begin{tabular}{|c|c|c|c|c|c|c|}
\hline input & $\mathrm{f}+\mathrm{E}$ & $\mathrm{t} 6+\mathrm{E}$ & $\mathrm{p}^{\mathrm{j}}+\mathrm{E}$ & $\mathrm{kj}$ & $\mathrm{tj}$ & $\mathrm{pj}$ \\
\hline output & $\mathrm{t}+\varepsilon$ & $\mathrm{t}_{6}+\varepsilon$ & $\mathrm{p}^{\mathrm{j}}+\varepsilon$ & $\mathrm{k}^{\mathrm{j} j}$ & $\mathrm{t}^{\mathrm{j} j}$ & $\mathrm{p}^{\mathrm{j} j}$ \\
\hline
\end{tabular}

The details of the ranking are as follows.

$$
\begin{aligned}
& \text { Level } 3 \text { ranking } \\
& \text { IDENT-C[-back], IDENT-Dor, IDENT[+anter], IDENT[-strid], IDENT- } \\
& \text { V[-back], PAL-Glide } \gg * \text { SOFT-Coron, *SOFT-Lab, } * \mathrm{k}^{\mathrm{j}},{ }^{*} \mathrm{~g}^{\mathrm{j}}, * \mathrm{x}^{\mathrm{j}}, \text { HARD, } \\
& \text { POSTER, STRID, } * \mathrm{t}_{6}, * \mathrm{t}^{\mathrm{j}}, \text { DE-PAL, IDENT-C[+back] } \gg \text { PAL-e }
\end{aligned}
$$

Level 3, the clitic level, is much like level 1, except for four facts. First, PAL-e is totally inert, so it is reranked below IDENT-C[+back]. Second, PAL-Glide is un-

\footnotetext{
${ }^{38}$ IDENT-C[-back] must be below HARD to permit Hardening: / $/ \mathrm{g}^{\mathrm{j}} \mathrm{g}^{\mathrm{j}} \mathrm{j}^{\mathrm{j}} / \rightarrow\left[\mathrm{t} \mathrm{d} \int \mathrm{f}\right]$.

${ }^{39}$ The ranking *SOFT-Coron $\gg$ IDENT-V[-back] is motivated by Vowel Retraction, $i \rightarrow i$ after a hard coronal; see the evaluation of Tirol $\rightarrow$ Tyrol in (87) below.

${ }^{40}$ Also before [i]; see the Appendix.
} 
dominated and surface-true because the glide causing Palatalization surfaces overtly in the phonetic representation. Third, Palatalization is of the secondary articulation type, $C \rightarrow C^{j}$, and, unlike at levels 1 and 2, does not lead to the change of place or manner of articulation. Fourth, even HARD that is exceptionless and undominated at level 2 now yields to PAL-Glide and $/ \mathrm{t} d \mathrm{f} /$ occurring before [j] end up as soft $\left[\mathrm{t}^{\mathrm{j}}\right.$ $\mathrm{g}^{\mathrm{j}} \mathrm{j}^{\mathrm{j}}$ ] because [j], which is an [i] at the melodic tier, is protected by the undominated IDENT-V[-back], so the disagreement in [ \pm back] in inputs such as $/ \mathrm{t} \mathrm{j} /$, as in zabacz. $j e$ 'see them', is resolved in favor of Palatalization at the expense of violating HARD: $/ \mathrm{t} \mathrm{j} / \rightarrow\left[\mathrm{t}^{\mathrm{j}} \mathrm{j}\right]$. The segment inventory constraints prohibiting soft consonants (here: *SOFT-Coron, $*$ SOFT-Lab, ${ }^{*} \mathrm{k}^{\mathrm{j}}{ }^{*} \mathrm{~g}^{\mathrm{j}}{ }^{*} \mathrm{x}^{\mathrm{j}}$ ) are bottom-ranked, so Palatalization derived by PAL-Glide prevails. DE-PAL plays no role, so it is bottom-ranked.

For the fragment of Polish phonology discussed in this article, levels 3 (clitic level) and 4 (postlexical sentence level) have the same ranking, so (73) is true for both of these levels.

The interactions summarized in this section are illustrated by a sample derivation that I take through all four levels. The example is the following fragment of a sentence: Z jej soczkiem jutro... [ $\mathrm{z}^{\mathrm{j}} \mathrm{j}$ j j $\operatorname{sot} \mathrm{fk}^{\mathrm{j}} \varepsilon \mathrm{m}^{\mathrm{j}}$ jutro] 'with her juice (dimin.) tomorrow...', where $z$ 'with' and jej 'her' are proclitics, soczk+iem is the instr.sg. of socz+ek, the diminutive of sok 'juice', and jutro 'tomorrow' is an adverb. The noun [sotf $\mathrm{k}^{\mathrm{j}}+\varepsilon \mathrm{m}$ ] contains the instr.sg. ending $/ / \mathrm{cm} / /$, which is a level 2 suffix. The level 1 input is therefore socz+ek//sok+Ek// 'juice' (dimin.). The diminutive suffix has a yer, compare the $[\varepsilon]-$ zero alternation in socz $+e k$ [sotf $+\varepsilon \mathrm{k}]$ (nom.sg.) $-\operatorname{soc} z+k+u[\operatorname{sot} f+\mathrm{k}+\mathrm{u}]$ (gen.sg.).

The derivation of $Z$ jej soczkiem jutro $\left[\mathrm{z}^{\mathrm{j}} \mathrm{j} \varepsilon \mathrm{j}\right.$ sot $\mathrm{gk}^{\mathrm{j}} \varepsilon \mathrm{m}^{\mathrm{j}} \mathrm{jutr}$ ] ' with her juice (dimin.) tomorrow' proceeds as follows. The words meaning 'juice' and 'tomorrow' begin their derivation at level 1 . The clitics $z$ 'with' and jej 'her' are not available until level 3.

Level $1 / / \mathrm{sok}+\mathrm{Ek} / / \rightarrow / \mathrm{sot}^{\mathrm{j}}+\mathrm{Ek} /$

\begin{tabular}{|c|c|c|c|c|c|}
\hline & $* \mathrm{k}^{\mathrm{j}} * \mathrm{~g}^{\mathrm{j}} * \mathrm{x}^{\mathrm{j}}$ DE-PAL & PAL-Glide & ID-C $[+\mathrm{bk}]$ & ID-Dor $*^{*} \mathrm{tc}$ & $* y^{j}$ \\
\hline a. sok+Ek & & & & & \\
\hline b. $\mathrm{sok}^{\mathrm{j}}+\mathrm{Ek}$ & *! & & * & & \\
\hline c. $s o t^{j}+E k$ & & & * & * & $*$ \\
\hline d. sot $6+E k$ & & & * & *! & \\
\hline
\end{tabular}

The winner $/ \mathrm{sot}^{\mathrm{j}}+\mathrm{Ek} / \mathrm{enters}$ level 2 , at which it picks up the instr.sg. suffix $-e m$ $/ / \mathrm{\varepsilon m} / /$, so the input to level 2 is $/ \mathrm{sot}^{\mathrm{j}}+\mathrm{Ek}+\varepsilon \mathrm{m} /$. Recall from Sect. 3 that level 2 has an active Yer Deletion constraint that deletes yers if they are followed by a single consonant and a full vowel, such as $/ \varepsilon / .^{41}$ The $/ \varepsilon /$ creates a context for Palatalization. The relevant constraint is PAL- $e$.

Level $2 /$ sot $^{\mathrm{j}}+\mathrm{Ek}+\varepsilon \mathrm{m} / \rightarrow\left[\operatorname{sot}^{\mathrm{j}} \mathrm{k}^{\mathrm{j}} \varepsilon \mathrm{m}\right]$

\begin{tabular}{|c|c|c|c|c|c|c|c|}
\hline & Yer Del & ID-Dor & HARD & ID-C[-bk] & PAL- $e$ & $\mathrm{ID}-\mathrm{C}[+\mathrm{bk}]$ & $* \mathrm{k}^{\mathrm{j}} *^{\mathrm{j}}$ \\
\hline a. $\operatorname{sot} f^{j}+E k+\varepsilon m$ & $* !$ & & * & & $*$ & & \\
\hline b. $\operatorname{sot}^{\mathrm{j}}+\mathrm{k}+\varepsilon \mathrm{m}$ & & & *! & & * & & \\
\hline c. $\operatorname{sot} f+k^{j}+\varepsilon m$ & & & & & & * & * \\
\hline d. $\operatorname{sot} f+t f+\varepsilon m$ & & $* !$ & & & * & & \\
\hline
\end{tabular}

${ }^{41}$ Yer Deletion is inactive at level 1 due to MAX $\gg$ Yer Del. 
At level 3, /sot $f+\mathrm{k}^{\mathrm{j}}+\varepsilon \mathrm{m} /$ picks up the proclitics $z$ 'with' and $j e j$ 'her'. Only the relevant constraints are shown.

Level $3 / \mathrm{z} \mathrm{j} \varepsilon j \operatorname{sotf} \mathrm{k}^{\mathrm{j}} \varepsilon \mathrm{m} / \rightarrow\left[\mathrm{z}^{\mathrm{j}} \mathrm{j} \varepsilon \mathrm{j} \operatorname{sot}^{\mathrm{j}} \mathrm{k}^{\mathrm{j}} \varepsilon \mathrm{m}\right]$

\begin{tabular}{|c|c|c|c|c|}
\hline & PAL-Glide & IDENT-C[-back] & IDENT[+anter] & ID-C[+back] \\
\hline a. z jej sot $\mathrm{k}^{\mathrm{j} \varepsilon \mathrm{c}}$ & *! & & & \\
\hline b. $z^{j}$ jej sotfkem & & *! & & * \\
\hline \& c. $z^{j} j^{j} \varepsilon j$ sotj $k^{j} \varepsilon m$ & & & & * \\
\hline d. zjej sotgk $\mathrm{k}^{\mathrm{j}} \mathrm{cm}$ & & & *! & * \\
\hline
\end{tabular}

The winner $/ \mathrm{z}^{\mathrm{j}} \mathrm{j} \varepsilon \mathrm{j} \operatorname{sot} \mathrm{k} \mathrm{k}^{\mathrm{j}} \mathrm{\varepsilon m} /$ 'with her juice' forms a sentence with jutro [jutro] 'tomorrow' and some other words. The adverb jutro has gone unscathed through all the levels, so the input to level 4 is /jutro/.

Level $4 / z^{\mathrm{j}}$ jej sot $\mathrm{k}^{\mathrm{j}} \varepsilon \mathrm{m}$ jutro/ $\rightarrow\left[\mathrm{z}^{\mathrm{j}} \mathrm{j} \varepsilon \mathrm{j} \operatorname{sot} \mathrm{gk} \mathrm{k}^{\mathrm{j}} \varepsilon \mathrm{m}^{\mathrm{j}}\right.$ jutro]

\begin{tabular}{|c|c|c|c|c|}
\hline & PAL-Glide & IDENT-C[-back] & IDENT[+anter] & ID-C[+back] \\
\hline a. $z^{j}$ jej sot $\mathrm{k}^{\mathrm{j}} \varepsilon \mathrm{m}$ jutro & $* !$ & & & \\
\hline b. $z^{j}$ jqj sot $k^{j} \varepsilon m^{j}$ jutro & & & & * \\
\hline
\end{tabular}

The string $\left[\mathrm{z}^{\mathrm{j}} \mathrm{j} \varepsilon \mathrm{s} \operatorname{sof} \mathrm{k}^{\mathrm{j}} \varepsilon \mathrm{m}^{\mathrm{j}}\right.$ jutro] with $/ \mathrm{m} /$ palatalized to $\left[\mathrm{m}^{\mathrm{j}}\right]$ through the action of PAL-Glide is the attested surface form.

\section{Conclusion}

Palatalization of velars in Modern Polish takes on two different guises: $k g x \rightarrow t \int$ of $\int$ and $k g \rightarrow k^{j} g^{j}$. In both cases the drivers are PAL-e and PAL-Glide. The effects, $[\mathrm{g} \mathrm{g}]$ and $\left[\mathrm{k}^{\mathrm{j}} \mathrm{g}^{\mathrm{j}}\right]$, respectively, are incompatible and cannot be derived in a strictly parallel manner postulated by Standard OT. They can, however, be accommodated by Derivational/Stratal OT that incorporates derivational levels. The distinction of levels is motivated further by segment inventory constraints that lead to ranking paradoxes on a massive scale in Standard OT.

A diachronic look at Surface Velar Palatalization shows the life cycle of the process. The analysis makes two points: first, a phonological process may enter the language by starting at level 2 rather than at level 4 and, second, a typical stage in the evolution of the process is the stage at which we see a restriction to derived environments. These are best modeled by postulating a separate constraint, DE-PAL, that is satisfied by structures spanning a morpheme boundary. In such analysis, it is unproblematic that the derived environment generalization may behave differently in different domains, that is, at different levels. DE-PAL makes correct predictions not only for an analysis of Polish, which exhibits Palatalization, but also for an analysis of Ukrainian, which exhibits Vowel Retraction, the reverse of Palatalization.

Derivational levels or strata show certain general characteristics. Levels 1 and 2, both of which are lexical (stem domain and word domain, respectively) are the locus of morphophonemic generalizations. Level 1 and level 2 are dramatically different, which is reflected in the number of constraint rerankings between these two levels. As we move to level 3 , the reranking of constraints diminishes significantly and, in the fragment of Polish phonology discussed here, it drops to zero at the transition 
between the postlexical levels: ${ }^{42}$ the clitic level and the sentence level. The postlexical levels exhibit Palatalization of the surface (allophonic) type: consonants become [-back] but their original manner and place of articulation are retained, so $k \rightarrow k^{j}$ is a typical postlexical process while $k \rightarrow t$, with its change of place (velar $\rightarrow$ posterior coronal) and manner of articulation (stop $\rightarrow$ affricate) is a typical lexical process. When, in addition to the postlexical levels, $k \rightarrow k^{j}$ occurs also at a lexical level, as it does in Polish (level 2), it is a transparent process in the sense that the trigger of Palatalization is present in the surface representation, as in cukier [tsuk ${ }^{\mathrm{j}} \varepsilon \mathrm{r}$ ] 'sugar'. The $k \rightarrow t$ process is not restricted in this way, so we see $[\mathrm{t}]$ in both the transparent alternation in bok 'side'- bocz+ek [botfek] (dimin., nom.sg.) and in the opaque alternation in bok - bocz+ka [botfka] (dimin., gen.sg.).

To conclude, the differences between levels are so substantial that it is fair to say that each level constitutes a separate grammar with its own inputs, evaluations, outputs, constraint ranking and inventories of admissible segments. The Derivational OT's claim is that there are four such grammars and that they are linked serially. An analysis of Surface Velar Palatalization has tested the derivational model and reaffirmed that it is adequate.

Acknowledgements I would like to thank three anonymous NLLT reviewers and Michael Kenstowicz for their discussion and criticism, which have led to considerable improvement of both the content and the presentation of my analysis. However, let me add that the responsibility for this paper is solely mine.

Open Access This article is distributed under the terms of the Creative Commons Attribution 4.0 International License (http://creativecommons.org/licenses/by/4.0/), which permits unrestricted use, distribution, and reproduction in any medium, provided you give appropriate credit to the original author(s) and the source, provide a link to the Creative Commons license, and indicate if changes were made.

\section{Appendix}

A reviewer asks how the analysis constructed for Palatalization before $e$ can be extended to Palatalization before $i$ and, further, how such an extended analysis would work not only for velars but also for coronals and labials. In what follows, I outline a scenario of how the reviewer's questions can be answered. ${ }^{43}$

As it turns out, extending the analysis to the context of $i$ strengthens rather than weakens the arguments for Derivational OT. Consider the following data.

$\begin{array}{lllll} & \text { nom.sg. } & \text { nom.pl. } & \text { diminutive } & \text { gloss } \\ \text { a. } & \text { hak [xak] } & \text { hak+i }\left[\mathrm{xak}^{\mathrm{j}}+\mathrm{i}\right] & \text { hacz+yk }[\mathrm{xatf}+\mathrm{ik}] & \text { 'hook' } \\ \text { b. } & \text { sklep [sklep] } & \text { sklep+y [sklep+i] } & \text { sklep+ik [sklep'+ik] } & \text { 'store' } \\ & \text { but [but] } & \text { but+y [but+i] } & \text { buc+ik [butc+ik] } & \text { 'shoe' }\end{array}$

\footnotetext{
${ }^{42}$ This is true for the fragment of Polish phonology analyzed here; it is unlikely to be true for the complete system of the constraints active in Polish phonology.

${ }^{43}$ Palatalization before $i$, unlike Palatalization before $e$, has been discussed by Rubach (2003 and 2017). The analysis outlined below supersedes the earlier analyses because it incorporates the results of the analysis in this paper, highlighting the role of segment inventory constraints.
} 
The velar palatalization example in (78a) appears to be problematic in both of the two theoretically relevant ways: the //k// does not palatalize to [t] in $h a k+i$, even though it is followed by $i$ and, second, the reverse: the $/ / \mathrm{k} / /$ palatalizes to $[\mathrm{t}]$ in hacz+yk [xatf+ik], even though it is not followed by a front vowel because [i], a central vowel, arguably counts as [+back] rather than as [-back]. These two behaviors of $/ / \mathrm{k} / /$ are accounted for without contradiction in Derivational OT. I begin with the second issue: $/ / \mathrm{k} / /$ changing into [ $\mathrm{f}]$ before [i] in hak 'hook' - hacz+yk [xatf+ik] (dimin.).

The diminutive suffix in [xatf+ik] occurs overtly with [i] if attached to stems ending in a labial, sklep 'store'- sklep+ik [sklep'+ik], or a coronal, but 'shoe' - buc+ik [butc+ik]. The underlying representation of the suffix is therefore //ik//, with //i// changing into [i] after the velar has palatalized to $/ \mathrm{t}^{\mathrm{j}} /$ and hardened to $[\mathrm{t}]$. The details are as follows.

At level 1, underlying //k// of //xak+ik// goes to $/ \mathrm{t}^{\mathrm{j} /}$ before $i$, exactly as it does in (16) in the context of $e, r y c z+e+\dot{c}$ 'scream': //rik $+\varepsilon+\mathrm{t} c / / \rightarrow / \mathrm{rit}^{\mathrm{j}}+\varepsilon+\mathrm{t} c /$, but the driver is not PAL- $e$ but PAL- $i$. Recall that level 1 is a Palatalization level, so IDENTV[-back] is undominated. PAL- $i$, like the other PAL constraints, is restricted to derived environments by DE-PAL (not shown in (79) below). Consequently, words such as $k i w+a+c$ 'nod', mogit $+a$ 'grave' and chichot 'chuckle' with morpheme-internal $k i$, gi, $x i$ retain their velars. ${ }^{44}$

Level $1 / / \mathrm{xak}+\mathrm{ik} / / \rightarrow / \mathrm{xat}^{\mathrm{j}}+\mathrm{ik} / 45$

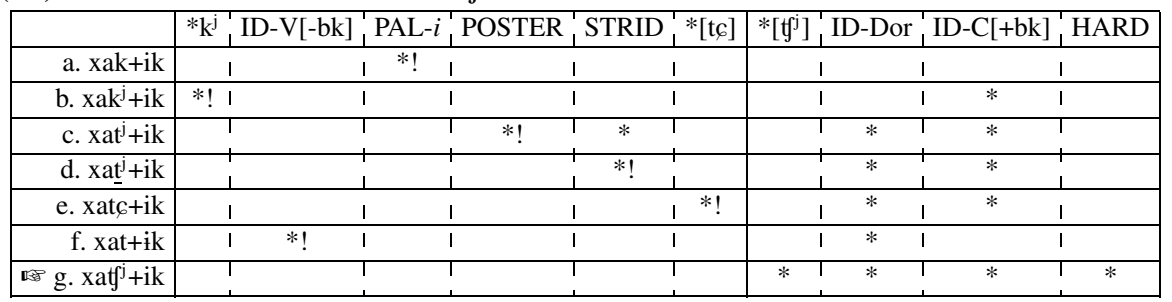

The level 1 grammar enforces $k \rightarrow t y^{j}$ by closing the possibility of satisfying PAL- $i$ by changing $/ / \mathrm{k} / /$ to $/ \mathrm{k}^{\mathrm{j}} /$. POSTER moves soft coronals to non-anteriors while STRID is responsible for affrication. The segment inventory constraints, *[tc] (no prepalatals) ranked above $*\left[\mathrm{t}^{\mathrm{j}}\right]$ (no postalveolars), make sure that the winning output has $\left[\mathrm{t}^{\mathrm{j}}\right]$ rather than $[\mathrm{tc}]$.

The derivation continues at level 2, at which HARD is reranked above IDENTV[-back] and IDENT-C[-back].

$$
\text { Level } 2 / \text { xatg }^{\mathrm{j}}+\mathrm{ik} / \rightarrow \text { [xatjik] }^{2}
$$

\begin{tabular}{|c|c|c|c|}
\hline & PAL- $i$, HARD & IDENT-C[-back] & IDENT-V[-back] \\
\hline a. $x^{2} f^{\mathrm{j}} \mathrm{ik}$ & $* !$ & & \\
\hline b. xatfik & $* !$ & $*$ & \\
\hline c. xatfik & 1 & $*$ & * \\
\hline
\end{tabular}

\footnotetext{
${ }^{44}$ The velars palatalize in a surface manner: $/ \mathrm{kg} \mathrm{x} / \rightarrow\left[\mathrm{k}^{\mathrm{j}} \mathrm{g}^{\mathrm{j}} \mathrm{x}^{\mathrm{j}}\right]$; see the analysis of hak+i 'hook' (nom.pl.) below.

${ }^{45}$ POSTER and STRID are outranked by IDENT[+anter] and IDENT[-strid], which is not shown in (79). In fact, POSTER and STRID can be bottom-ranked at level 1.
} 
The example with a coronal stem in (78b), but 'shoe' - buc+ik [but6+ik] (dimin.), is different from the velar stem example, hak 'hook' - hacz+yk (dimin.), because it is subject to IDENT[+anter] and IDENT[-strid], the constraints that have jurisdiction over coronals but not over velars. ${ }^{46}$ The level 1 grammar selects $/ \mathrm{but}^{\mathrm{j}}+\mathrm{ik} /$ as the winner. To keep the tableau within manageable bounds, I suppress IDENT-C [+back] that is low-ranked and violated by all Palatalization candidates. I also omit HARD, which plays no role in this evaluation.

(81) $\quad$ Level $1 / /$ but $+\mathrm{ik} / / \rightarrow /$ but $^{\mathrm{j}}+\mathrm{ik} /$

\begin{tabular}{|c|c|c|c|c|c|c|c|c|c|c|}
\hline & ID-V[-bk] & PAL & 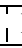 & $\tan$ & 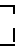 & ID[-strid] & POSTER & STRID & $*\left[\mathrm{t}_{6}\right]$ & $*\left[\mathrm{t}^{\mathrm{j}}\right]$ \\
\hline a. but+ik & & $* !$ & 1 & & 1 & & 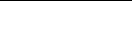 & I & I & \\
\hline b. but ${ }^{\mathrm{j}}+\mathrm{ik}$ & & $T$ & 1 & & 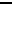 & & $*$ & $*$ & $T$ & \\
\hline c. buts ${ }^{j}+i k$ & & | & 1 & & 1 & $* !$ & $*$ & | & 1 & \\
\hline d. but $\underline{t}^{\mathrm{j}}+\mathrm{ik}$ & & I & 1 & $* !$ & r & & & $*$ & 1 & \\
\hline e. butc+ik & & $\perp$ & 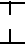 & $* !$ & 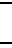 & $*$ & & 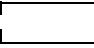 & $\begin{array}{ll}1 & * \\
\end{array}$ & \\
\hline f. but+ik & $* !$ & I & 1 & & & & & I & I & \\
\hline g. but ${ }^{j}+i k$ & & I & 1 & $* !$ & 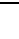 & $*$ & 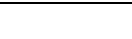 & 1 & $T$ & $*$ \\
\hline
\end{tabular}

As observed in (20)-(21), the Level 2 grammar reranks POSTER and STRID above IDENT[+anter] and IDENT[-strid], so the enhancement $/ \mathrm{t}^{\mathrm{j}} / \rightarrow$ [t 6 ] is now enforced in the optimal candidate. Additionally, the reranking of the segment inventory constraints from $*\left[\mathrm{t}_{c}\right] \gg *\left[\mathrm{t}^{\mathrm{j}}\right]$ at level 1 to $*\left[\mathrm{t}^{\mathrm{j}}\right] \gg *[\mathrm{t} c]$ at level 2 makes sure that the non-anterior stridents are prepalatals rather than postalveolars, so we derive [butcik] rather than [but ${ }^{\mathrm{j} i k]}$. IDENT-C [-back] guarantees that the input $/ \mathrm{t}^{\mathrm{j}} /$ cannot depalatalize to $[\mathrm{t}]$.

(82) Level $2 /$ but $^{\mathrm{j}}+\mathrm{ik} / \rightarrow$ [butcik]

\begin{tabular}{|c|c|c|c|c|c|c|c|}
\hline & IDENT-C[-bk] & POSTER & STRID & IDENT[+anter] & IDENT[-strid] & $* \mathrm{tg}^{\mathrm{j}}$ & $* t_{6}$ \\
\hline a. but $\mathrm{j}^{\mathrm{i} k}$ & & $* !$ & $*$ & I & । & । & \\
\hline b. but ${ }^{\mathrm{j}} \mathrm{ik}$ & & & $* !$ & $*$ & I & I & \\
\hline c. buts ${ }^{\mathrm{j}} \mathrm{ik}$ & & $* !$ & $T$ & & $*$ & $T$ & \\
\hline d. butfjik & & & 1 & $*$ & $*$ & $* !$ & \\
\hline e. butcik & & & 1 & $*$ & $*$ & I & $*$ \\
\hline f. but+ik & $* !$ & & $T$ & & $T$ & $T$ & \\
\hline
\end{tabular}

The optimal candidate [butcik] is the attested surface form.

In the case of labial stems, such as sklep 'store' - sklep+ik (dimin.) in (78b), the level 1 grammar selects [sklep $p^{j}+\mathrm{ik}$ ] as the optimal output. The level 2 derivation does not change anything. The loss of palatalization, $p^{j} \rightarrow p$, is made impossible by IDENT-C[-back] being ranked above *SOFT-Lab, so the faithful [sklep $\left.\mathrm{p}^{\mathrm{j}}+\mathrm{ik}\right]$ emerges as the winner. The result is correct.

Returning to the data in (78), the nom.pl. hak+i 'hooks' appears to be problematic because we see [i], a trigger of $/ / \mathrm{k} / / \rightarrow / \mathrm{f}^{\mathrm{j}} /$, and yet the $/ \mathrm{k} /$ is retained, albeit palatalized in a surface manner, $k \rightarrow k^{j}$ [xak $\left.{ }^{\mathrm{j}} \mathrm{i}\right]$. The key to the analysis lies with the data in (78b), such as but $+y$ [but $+\dot{i}]$ 'shoes'. We see that the nom.pl. ending surfaces as [i] and the occurrence of [i] is limited to the context of velar stops (Rubach 1984). The generalization extends beyond suffixes: [ki], [gi] are not licit strings in Polish. The

${ }^{46}$ As noted in Sect. 1.1, this jurisdiction follows from the fact that $[ \pm$ anter $]$ and $[ \pm$ strid] are dependents of the CORONAL node. 
analysis of $h a k+i$ is to assume //i $/ /$ in the underlying representation and have $/ / \mathbf{i} / /$ front to [i] after velar stops. In terms of OT, the generalization is stated as a phonotactic constraint on permissible collocations.

\section{Velar Fronting (VEL-Fronting): No [ki], [gi] .}

Armed with VEL-Fronting, the analysis falls into place. The underlying representation of $h a k+i$ is //xak $+\mathbf{i} / /$. The / $\mathbf{i} /$ persists through level 1, an effect of IDENT$\mathrm{V}$ [+back] ranked above VEL-Fronting. Since / $\mathbf{i} /$ is [+back], it is clear why Velar Palatalization, $/ / \mathrm{k} / / \rightarrow\left[\mathrm{t}^{\mathrm{j}}\right]$, does not take place in the winning candidate. At level 2, VEL-Fronting is reranked above IDENT-V[+back], so the candidate with [ki] is doomed. The details of the interaction are laid out in the following tableaux. Irrelevant constraints are omitted.

(i) Level $1 / / \mathrm{xak}+\dot{\mathrm{i}} / / \rightarrow / \mathrm{xak}+\dot{\mathrm{i}} /$ (no change)

\begin{tabular}{|c|c|c|c|c|}
\hline & PAL- $i$ & IDENT-V[+back] & VEL-Fronting & IDENT-Dor \\
\hline a. $x a k+\dot{t}$ & I & & $*$ & i \\
\hline b. $x a k+i$ & $* !$ & $*$ & & $\Gamma$ \\
\hline c. $x a k^{j}+i$ & । & *! & & I \\
\hline d. $x a t f^{j}+i$ & T & $* !$ & & * \\
\hline
\end{tabular}

(ii) Level $2 / \mathrm{xak}+\mathrm{i} / \rightarrow / \mathrm{xak}^{\mathrm{j}} \mathrm{i} /$

\begin{tabular}{|c|c|c|c|}
\hline & IDENT-Dor PAL- $i$ & VEL-Fronting & IDENT-V[+back] \\
\hline a. $x a k+i$ & 1 & $* !$ & \\
\hline b. $x a k+i$ & $* !$ & $\Gamma$ & $*$ \\
\hline c. $x \mathrm{xak}^{\mathrm{j}}+\mathrm{i}$ & I & 1 & $*$ \\
\hline d. $x t^{j}+i$ & $* !$ & i & $*$ \\
\hline
\end{tabular}

As argued in Sect. 3, IDENT-Dor is reranked to an undominated position at level 2. VEL-Fronting takes effect because it is reranked above IDENT-V[+back], as shown in (84ii).

In the class of coronals, the differences between the effects of level 1 and level 2 are by far greater than in the class of velars. In the latter, the difference between levels is a matter of what type of palatalizing changes occur: $k \rightarrow t^{j}$ at level 1 vs. $k \rightarrow k^{j}$ at level 2. In the case of coronals, Palatalization, for example, $t \rightarrow t^{j}$, occurs at level 1 . At level 2, the effects of Palatalization are enhanced by affrication and change of the place of articulation from dental to prepalatal: $t^{j} \rightarrow t 6$, as shown in the evaluation of bractie 'brother' (voc.sg.) in (21). More importantly, the level 2 grammar switches gears from Palatalization to Vowel Retraction (Retraction, henceforth), so from $\mathrm{Ci}$ $\rightarrow C^{j} i$ at level 1 to $C i \rightarrow C \dot{i}$ at level $2 .{ }^{47}$ By force majeure, Retraction cannot occur across morpheme boundaries because this is the context in which consonants undergo Palatalization at level 1 , so $/ / \mathrm{t}+\mathrm{i} / / \rightarrow / \mathrm{t}^{\mathrm{j}}+\mathrm{i} /$. As a consequence of Palatalization, the input to level 2 is $/ \mathrm{t}^{\mathrm{j}}+\mathrm{i} /$, which thwarts Retraction because Retraction is triggered by hard coronals. To conclude, Retraction operates morpheme-internally and hence we see no alternations. ${ }^{48}$

\footnotetext{
${ }^{47}$ Recall from the introductory section that both Palatalization and Vowel Retraction satisfy PAL-i.

${ }^{48}$ Actually, I know of one case of alternation. It is the word ekspedy $+c j+a$ [di] 'expedition' $-e k s$ pedi+owa $+\hat{c}\left[\mathrm{~d}_{\mathrm{j}}^{\mathrm{j}}\right]$ 'send promptly'. The $[\mathrm{j}]$ in the verb is part of the root because the suffix is $-o w a+c$, as
} 
Evidence for Retraction comes from assimilation of borrowings (Rubach 1984). The data in (85) below show that Retraction, $i \rightarrow \dot{i}$, occurs after coronals (85a) but not after labials or velars (85b).

a. German Siegfried [zikfrit] $\rightarrow$ Polish Zygfryd [zikfrit] (first name)

German Tirol [ti] $\rightarrow$ Polish Tyrol [ti] (name of a state in Austria)

Latin medicus [di] $\rightarrow$ Polish medyk [di] 'doctor'

Latin maxima [si] $\rightarrow$ Polish maksym+a [si] 'maxim'

b. French pilote [pi] $\rightarrow$ Polish pilot [p'i] 'pilot'

German Kabine [bi] $\rightarrow$ Polish kabina [b $\mathrm{b}_{\mathrm{i}}^{\mathrm{i}]}$ 'cabin'

German Kittel [ki] $\rightarrow$ Polish kitel [kjitel] 'apron'

German Gips [gi] $\rightarrow$ Polish gips [g ${ }^{\mathrm{j} i p s]}$ 'plaster'

Switching gears from Palatalization at level 1 to Retraction at level 2 means that *SOFT-Coron overrides IDENT-V[-back]. That is:

$$
\begin{aligned}
& \text { Level 1: IDENT-V[-back] } \gg * \text { SOFT-Coron enforces } / / \mathrm{t}+\mathrm{i} / / \rightarrow / \mathrm{t}^{\mathrm{j}}+\mathrm{i} / \\
& \text { Level 2: } * \text { SOFT-Coron } \gg \text { IDENT-V[-back] enforces } / \mathrm{ti} / \rightarrow[\mathrm{ti}]
\end{aligned}
$$

In addition, DE-PAL $\gg$ PAL- $i$ at level 1 , limiting the jurisdiction to derived environments, is changed to PAL- $i \gg$ DE-PAL at level 2, which opens morpheme-internal strings to PAL- $i$.

An evaluation of Tirol $\rightarrow$ Tyrol (name of a region) shows how Retraction is implemented. Nothing happens at level 1 because //ti// does not span a morpheme boundary, so DE-PAL eliminates the Palatalization candidate. The input to level 2 is therefore $/ \mathrm{ti} /$.

Level 2 /tirol/ $\rightarrow$ /tirol/

\begin{tabular}{|c|c:c|c|c|}
\hline & Pal- $i$ & IDENT-C[-back] & $*$ SOFT-Coron & IDENT-V[-back] \\
\hline a. tirol & $* !$ & & \\
\hline b. t $^{\text {jirol }}$ & $:$ & $* !$ & \\
\hline c. tirol & r & & $*$ \\
\hline
\end{tabular}

Candidate $(87 \mathrm{c})$ is the attested surface form.

shown by plan 'plan' - plan+owa+ć 'to plan'. The [j] in ekspedi+owa+ć must come from //i// as //i// and not $/ / \mathrm{i} / /$ is the source of Gliding: $i \rightarrow \mathrm{j} /-\mathrm{V}$. Therefore, the underlying representation of ekspedi+owa+ć is //عkspedi+ova+tc//. Consequently, the underlying representation of $e k s p e d y+c j+a\left[\varepsilon k s p \varepsilon d i+\mathrm{ts}^{\mathrm{j}} \mathrm{j}+\mathrm{a}\right]$ must also have //i//. The surface [i] in ekspedy $+c j+a\left[\varepsilon k s p \varepsilon d i+{ }_{s} j_{j}+a\right]$ is derived by Retraction: $i \rightarrow i$ after a hard coronal.

Also, an alternation may arise if two forms of a borrowing coexist: one is a foreign citation form and the other is an assimilated form. This is what we find with maksim $+u m$ [i] 'maximum' $-m a k s y m+a l+n+y$ [si] 'maximal'. The former has retained the Latin [i] and the Latin stress pattern (stress on $\boldsymbol{a}$ while the native Polish stress is penultimate). On the other hand, the adjective maksym $+\boldsymbol{a} l+n+y$ (the bolded vowel carries stress) has assimilated to the native pattern by adding the Polish adjectivizing morpheme $-n$ and the inflectional ending $-y$. (Stress is also native as it falls on the penultimate syllable.) Unsurprisingly, the assimilated form shows [i] , an effect of Retraction: $s i \rightarrow s \dot{i}$. The same effect typically occurs in the noun maksim+um once stress moves to the penultimate syllable, thereby exhibiting the native pattern: [ma'ksimum]. 
The fact that PAL- $i$ is implemented as Retraction at level 2 has no adverse consequences for the derivation of prepalatals, as in but 'shoe' - buc+ik (dimin.). Recall that $b u c+i k$ leaves level 1 as $/ \mathrm{but}^{\mathrm{j}}+\mathrm{ik} /$. The derivation continues at level 2 .

Level $2 /$ but $^{\mathrm{j}}+\mathrm{ik} / \rightarrow$ [butcik]

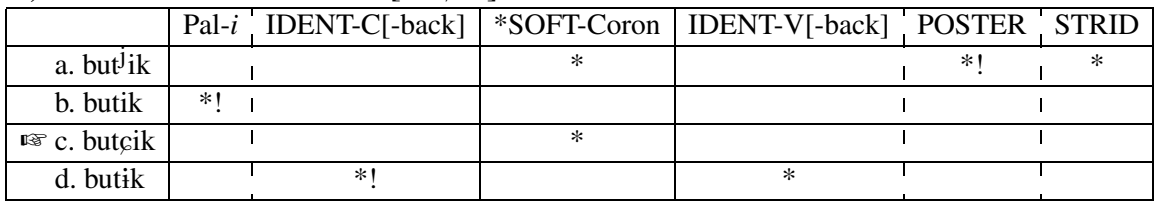

As the data in (85) show, Retraction as a response to PAL- $i$ at level 2 is limited to coronals (85a). Labials and velars undergo Palatalization (85b), like they do at level 1 , but with the notable difference that PAL- $i$ is not limited to derived environments: PAL- $i \gg$ DE-PAL at level 2. Palatalization is found with both native words (89a) and loanwords (89b).

\section{a. Native vocabulary pisk [ $\mathrm{p}^{\mathrm{j}}$ isk] 'scream' bi+ć $\left[b^{j}{ }^{i t c}\right]$ 'beat' miły [ $\mathrm{m}^{\mathrm{j}}$ iwi] 'nice' \\ b. Loanwords}

French pirouette French billet

English mixer

German Kino

Latin machina

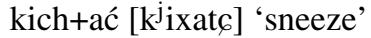

gibk+i $\left[\mathrm{g}^{\mathrm{j} i p k} \mathrm{j}_{\mathrm{i}}^{\mathrm{j}}\right.$ ' 'agile'

chichot $\left[\mathrm{x}^{\mathrm{j}}\right.$ ixot $]$ 'chuckle'

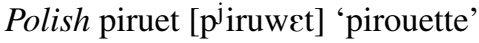

Polish bilet [ $\left.\mathrm{b}^{\mathrm{j}} \mathrm{ilet}\right]$ 'ticket'

Polish mikser [mikser] 'mixer'

Polish kin+o [kjino] 'cinema'

Polish machina [max ${ }^{\mathrm{j} i n a]}$ 'machinery'

Palatalization, the desired effect for labials and velars, $p i \rightarrow p^{j} i$ and $k i \rightarrow k^{j} i$, is obtained at level 2 if IDENT-V[-back] outranks IDENT-C[+back] and *SOFT-Lab as well as the constraints against palatalized velars $\left({ }^{*} \mathrm{k}^{\mathrm{j}},{ }^{*} \mathrm{~g}^{\mathrm{j}},{ }^{*} \mathrm{x}^{\mathrm{j}}\right)$. In (90), I look at the palatalization of pisk //pisk// 'scream'. As noted earlier, nothing happens at level 1 because $p i$ does not span a morpheme boundary, so the output from level 1 is the faithful /pisk/.

Level $2 /$ pisk/ $\rightarrow\left[\mathrm{p}^{\mathrm{j}}\right.$ isk $]$

\begin{tabular}{|r|c|c|c|c|}
\hline & Pal- $i$ & IDENT-V[-back $]^{49}$ & $*$ SOFT-Lab & IDENT-C [+back] \\
\hline a. pisk & $* !$ & & & \\
\hline b. pisk & & $* !$ & & \\
\hline c. $\mathrm{p}^{\mathrm{j} i \mathrm{isk}}$ & & & $*$ & $*$ \\
\hline
\end{tabular}

Palatalization wins also with velar inputs. Recall that morpheme-internal //ki// goes unscathed through level 1 because all PAL constraints are dominated by DE-PAL, barring looking inside morphemes. The action begins at level 2, where DE-PAL is reranked below PAL- $i$.

${ }^{49}$ Unlike PAL-i, IDENT-V[-back] is dominated at level 2: as shown in (87), it is ranked below *SOFTCoron. 
(91) Level $2 / \mathrm{kin}+\mathrm{J} / \rightarrow\left[\mathrm{k}^{\mathrm{j}}\right.$ ino $]$

\begin{tabular}{|c|c|c|c|}
\hline & Pal- $i$ & IDENT-V[-back] & $\begin{array}{llll}* \text { SOFT-Lab } & * \mathrm{k}^{\mathrm{j}} * \mathrm{~g}^{\mathrm{j}} * \mathrm{x}^{\mathrm{j}} & \text { IDENT-C }[+ \text { back }]\end{array}$ \\
\hline a. kins & $* !$ & & \\
\hline b. kins & & *! & \\
\hline c. $\mathrm{k}^{\mathrm{j}_{\text {in }}}$ & & & * \\
\hline
\end{tabular}

The operation of PAL- $i$ at levels 3 and 4 is parallel to the operation of PAL-Glide shown in (52), so I use the same or similar examples.

a. PAL- $i$ at level 3

$\mathrm{z}+$ ignorować 'ignore' (perfective), $\left[\mathrm{z}^{\mathrm{j}}+\mathrm{i}\right]$, not $*[\mathrm{z}+\mathrm{i}]$, not $*[\mathrm{z}+\mathrm{i}]$

nad+inspektor 'police general', $\left[\mathrm{d}^{\mathrm{j}}+\mathrm{i}\right]$, not $*[\mathrm{~d}+\mathrm{i}]$, not $*[\mathrm{~d}+\mathrm{i}]$

krok $i$ ch 'their step', [ $\left.\mathrm{k}^{\mathrm{j}} \mathrm{i}\right]$, not $*[\mathrm{ki}]$, not $*[\mathrm{k} \mathrm{i}]$

duch ich 'their spirit', $\left[\mathrm{x}^{\mathrm{j}} \mathrm{i}\right]$, not $*[\mathrm{x} \dot{\mathrm{i}}]$, not $*[\mathrm{x} i]$

brat $i$ ch 'their brother', [ $\left[\mathrm{t}^{\mathrm{j}} \mathrm{i}\right]$, not $*[\mathrm{t} \mathrm{i}]$, not $*[\mathrm{t} \mathrm{i}]$

skecz $i$ ch 'their sketch', [t $\left.{ }^{\mathrm{j}} \mathrm{i}\right]$, not $*[\mathrm{t} \mathrm{j}]$, not $*\left[\mathrm{t}^{\mathrm{i}}\right]$

sklep $i$ ch 'their grave', $\left[\mathrm{p}^{\mathrm{j}} \mathrm{i}\right]$, not $*[\mathrm{p} i]$, not $*[\mathrm{p} \mathrm{i}]$

b. PAL- $i$ at level 4

krok Ireny 'Irene's step', [ $\left.\mathrm{k}^{\mathrm{j}} \mathrm{i}\right]$, not *[k i], not *[k i]

duch Ireny 'Irene's spirit', [x $\left.{ }^{\mathrm{j}} \mathrm{i}\right]$, not $*[\mathrm{x} i \mathrm{i}]$, not $*[\mathrm{x} i]$

brat Ireny 'Irene's brother', [ $\left.\mathrm{t}^{\mathrm{j}} \mathrm{i}\right]$, not $*[\mathrm{t} \mathrm{i}]$, not $*[\mathrm{t} \mathrm{i}]$

skecz Ireny 'Irene's sketch', [t $\left.\mathrm{t}^{\mathrm{j}} \mathrm{i}\right]$, not $*[\mathrm{t} \mathrm{i}]$, not $*[\mathrm{t} \mathrm{i}]$

skle $p$ Ireny 'Irene's grave', [p $\left.p^{\mathrm{j}} \mathrm{i}\right]$, not *[p i] , not *[p i]

The ranking of the constraints at levels 3 and 4 returns in many ways to the ranking at level 1. PAL- $i$ manifests itself as Palatalization, $C \rightarrow C^{j}$, rather than as Retraction, $i \rightarrow i$. Palatalization is not accompanied by enhancement via POSTER and STRID, so /t d s z/ turn into $\left[\mathrm{t}^{\mathrm{j}} \mathrm{d}^{\mathrm{j}} \mathrm{s}^{\mathrm{j}} \mathrm{z}^{\mathrm{j}}\right.$ ] and not into [t6(k, $\mathrm{k}$ ]. HARD has no force as PAL- $i$ produces soft $\left[\mathrm{t}^{\mathrm{j}} \mathrm{f}^{\mathrm{j}}\right]$ that do not harden to [tf]].

Reranking at level 3
a. Level 2
*SOFT-Coron $\gg$ IDENT-V[-back]
Level 3
IDENT-V[-back] $\gg * S O F T-C o r o n$
b. Level 2
POSTER, STRID $\gg$ IDENT[+anter], IDENT[-strid]
Level 3
IDENT[+anter], IDENT[-strid] $\gg$ POSTER, STRID
c. Level 2
HARD $\gg$ IDENT-V[-back]
Level 3
IDENT-V[-back] $\gg$ HARD

The evaluation in (94) looks at the prefix plus stem structure in the verb z+ignorowac 'ignore' (perfective). Since $z$ is a prefix, it becomes first available for evaluation at level 3, that is, it never goes through levels 1 and 2. In (94), I look at the /z+i/ portion of z+ignorować.

\begin{tabular}{|c|c|c|c|c|}
\hline & PAL- $i$, IDENT-V[-back] & *SOFT-Coron & IDENT[+anter] & POSTER \\
\hline a. zi & $* !$ & 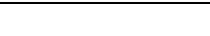 & & \\
\hline b. $\mathrm{zi}$ & $* !$ & 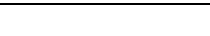 & & \\
\hline c. $z^{\mathrm{j}} \mathrm{i}$ & I & $*$ & & $*$ \\
\hline d. zi & 1 & $*$ & $* !$ & \\
\hline
\end{tabular}


To conclude, the analysis in Sect. 3 is readily extended to include PAL- $i$ as the driver and coronals as well as labials as the inputs. The theoretical conclusions in Sect. 6 are strengthened by these extensions. PAL- $i$ demonstrates that levels 1 and 2 differ dramatically in the types of operation that are conducted and the segment inventory constraints that play an active role in selecting the correct output. Level 1 is a Palatalization level, $C i \rightarrow C^{j} i$, while level 2 is a Retraction level, $C i \rightarrow C \dot{i}$. At level 1, PAL- $i$ is restricted to derived environments while at level 2 it applies freely inside morphemes. The admissible Palatalization outputs for coronals are $/ \mathrm{t}^{\mathrm{j}} \mathrm{d}^{\mathrm{j}} \mathrm{s}^{\mathrm{j}} \mathrm{z}^{\mathrm{j}} /$ at level 1 . At level 2, $/ \mathrm{t}^{\mathrm{j}} \mathrm{d}^{\mathrm{j}} \mathrm{s}^{\mathrm{j}} \mathrm{z}^{\mathrm{j}} /$ are inadmissible, so they are changed into [t $\mathrm{t} \mathrm{d}, 6 \mathrm{z}$ ]. At levels 3 and 4 , the admissible soft coronals are the same as at level 1 : $\left[\mathrm{t}^{\mathrm{j}} \mathrm{d}^{\mathrm{j}} \mathrm{s}^{\mathrm{j}} \mathrm{z}^{\mathrm{j}}\right]$. The Velar

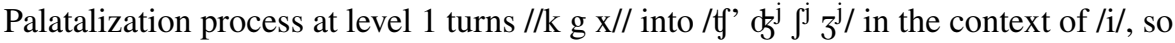
the process is transparent. The change becomes opaque at level 2, where HARD, a segment inventory constraint, enforces the loss of Palatalization: / $t \mathrm{f}^{\prime} \mathrm{d}^{\mathrm{j}} \int^{\mathrm{j}} 3^{\mathrm{j}} / \rightarrow\left[\mathrm{t} d \mathrm{~d} \int\right.$ 3], which in turn entails the change of the vowel from front to back: Retraction, /i/ $\rightarrow$ [i]. This is what we saw in hacz+yk 'hook' (dimin.): //xak+ik// $\rightarrow / \mathrm{xat} f^{\mathrm{j}} \mathrm{ik} /$ at level 1 and $/ \mathrm{xat} \mathrm{f}^{\mathrm{j}} \mathrm{ik} / \rightarrow$ [xatfik] at level 2 . The processes at level 2 destroy the transparency of Palatalization because in the surface representation we see an alternation between [k] in hak [xak] 'hook' and [t] in hacz+yk [xatfik] (dimin.), where [ $\mathrm{g}]$ occurs before a [+back] vowel.

Coronals palatalize at level 1 by acquiring the feature [-back], so //z+i// $\rightarrow / \mathrm{z}^{\mathrm{j}} \mathrm{i} /$ at level 1 and further $/ z^{j} / \rightarrow$ [z] at level 2 , as in uraz 'injury' - uraz+i+ć [urazitc] 'hurt'. This happens in derived environments. Morpheme-internal /zi/ goes to [zi] at level 2, a Retraction effect, as in the assimilation of the German name Siegfried as Zygfryd in Polish: /zikfrit/ $\rightarrow$ [zikfrit]. Level 3 inputs with prefixes revert to the strategy for accommodating PAL- $i$ as Palatalization, as in $z+$ ignorować $\left[\mathrm{z}^{\mathrm{j}} \mathrm{i}\right]$ 'ignore', but, unlike in $u r a z+i+c$ there is no follow-up by enhancing $/ z^{j} /$ to [z] at the next level.

A general conclusion that emerges from the investigation of PAL- $i$ and from the extension of inputs from velars alone to coronals and labials concurs with the conclusion in Sect. 6: disparate effects of PAL- $i$ require different grammars with different constraint ranking and different inventories. Derivational OT is exactly the paradigm that can accommodate these requirements.

\section{References}

Antilla, Arto. 2002. Morphologically conditioned phonological alternations. Natural Language and Linguistic Theory 20: 1-24.

Antilla, Arto. 2008. Derived environment effects in colloquial Helsinki Finnish. In The nature of the word: Studies in honor of Paul Kiparsky, eds. Sharon Hargus and Ellen M. Kaisse, 433-459. Cambridge: MIT Press.

Avanesov, Ruben I. 1968. Russkoye literaturnoye proiznoshenie. Moscow: Prosveshchenie.

Baudouin de Courtenay, Jan. 1894. Próba teorji alternacyj fonetycznych. Rozprawy Wydziału Filologicznego 20: 219-367. Translated: 1972. An attempt at a theory of phonetic alternations. In Baudouin de Courtenay anthology, ed. Edward Stankiewicz, 144-212. Bloomington: Indiana University Press.

Baudouin de Courtenay, Jan, Aleksander Brückner, Antoni Kalina, Jan Karłowicz, and Adam Kryński. 1899. Sprawa przyjęcia jednolitej pisowni proponowanej przez Akademię Umiejętności w Krakowie. Prace Filologiczne 5: 159-185.

Benua, Laura. 1997. Transderivational identity: Phonological relations between words. PhD diss., University of Massachusetts, Amherst [ROA-259] 
Bermúdez-Otero, Ricardo. 1999. Constraint interaction in language change: Quantity in English and Germanic. PhD diss., University of Manchester.

Bermúdez-Otero, Ricardo. 2007. Diachronic phonology. In The Cambridge handbook of phonology, ed. Paul de Lacy, 497-517. Cambridge: Cambridge University Press.

Bermúdez-Otero, Ricardo. 2013. Amphichronic explanation and the life cycle of phonological processes. In The Oxford handbook of historical phonology, eds. Patrick Honeybone and Joseph C. Salmons, 374-399. Oxford: Oxford University Press.

Bermúdez-Otero, Ricardo. 2018. Stratal phonology. In The Routledge handbook of phonological theory, eds. S. J. Hannahs and Anna R. K. Bosch, 100-134. Abington: Routledge.

Bethin, Christina Y. 1992. Polish syllables: The role of prosody in phonology and morphology. Columbus: Slavica Publishers.

Bilodid, I. K. 1969. Suchasna ukrä̈ns'ka literaturna mova. Fonetyka. Kiev: Naukova Dumka.

Booij, Geert E., and Jerzy Rubach. 1987. Postcyclic versus postlexical rules in lexical phonology. Linguistic Inquiry 18: 1-44.

Chen, Matthew. 1973. Predictive power in phonological description. Lingua 32: 173-191.

Czaykowska-Higgins, Ewa. 1988. Investigations into Polish morphology and phonology. PhD diss., MIT.

Długosz-Kurczabowa, Krystyna, and Stanisław Dubisz. 2006. Gramatyka historyczna jezyka polskiego. Warszawa: Wydawnictwa Uniwersytetu Warszawskiego.

Dogil, Grzegorz. 1990. Hissing and hushing fricatives: A comment on non-anterior spirants in Polish. Ms., University of Bielefeld.

Guion, Susan G. 1996. Velar palatalization: Coarticulation, perception, and sound change. PhD diss., University of Texas, Austin.

Gussmann, Edmund. 1980. Studies in abstract phonology. Cambridge: MIT Press.

Hall, Tracy A. 2006. Derived environment blocking effects in optimality theory. Natural Language and Linguistic Theory 24: 803-856.

Halle, Morris. 1992. Phonological features. In International encyclopedia of linguistics, ed. William Bright, 207-212. Oxford: Oxford University Press.

Halle, Morris, and Kenneth N. Stevens. 1997. The postalveolar fricatives of Polish. In Speech production and language, eds. Shigeru Kiritani, Hajime Hirose and Hiroya Fujisaki, 177-193. Berlin: Mouton de Gruyter.

Hyman, Larry M. 1976. Phonologization. In Linguistic studies offered to Joseph Greenberg, ed. Alphonse Juilland, 407-418. Saratoga: Anma Libri.

Inkelas, Sharon. 2000. Phonotactic blocking through structural immunity. In Lexicon in focus, ed. Barbara Stiebels and Dieter Wunderlich, 7-40. Berlin: Akademie Verlag.

Itô, Junko, and Armin Mester. 2003. On the sources of opacity in OT: Coda processes in German. In The syllable in optimality theory, eds. Caroline Féry and Ruben van der Vijver, 271-303. Cambridge: Cambridge University Press.

Jeske August. 1800. Gramatyka jezyka polskiego. Chicago: Polish-American Publishing Company. Reprint of the 8th edition.

Kawasaki, Haruko. 1982. An acoustic basis for universal constraints and sound sequences. PhD diss., University of California, Berkeley.

Kenstowicz, Michael, and Jerzy Rubach. 1987. The phonology of syllabic nuclei in Slovak. Language 63: 463-497.

Kiparsky, Paul. 1968. Linguistic universals and linguistic change. In Universals in linguistic theory, eds. Emmon Bach and Robert T. Harms, 170-202. New York: Holt, Rinehart and Winston.

Kiparsky, Paul. 1973. How abstract is phonology? In Three dimensions in phonological theory, ed. Osamu Fujimura, 5-56. Tokyo: TEC Company.

Kiparsky, Paul. 1982. From cyclic to lexical phonology. In The structure of phonological representations, eds. Harry van der Hulst and Norval Smith. Vol. 1, 131-175. Dordrecht: Foris Publications.

Kiparsky, Paul. 1993. Blocking in nonderived environments. In Phonetics and phonology 4: Studies in lexical phonology, eds. Sharon Hargus and Ellen M. Kaisse, 277-313. San Diego: Academic Press.

Kiparsky, Paul. 1997. LP and OT. Handout. Ithaca: Cornell Linguistic Institute.

Kiparsky, Paul. 2013. Phonologization. In The Oxford handbook of historical phonology, eds. Patrick Honeybone and Joseph C. Salmons, 563-582. Oxford: Oxford University Press.

Kiparsky, Paul. 2015. Stratal OT: A synopsis and FAQs. In Capturing phonological shades within and across languages, eds. Yuchau E. Hsiao and Lian Hee Wee, 2-44. Newcastle upon Tyne: Cambridge Scholars Publishing.

Kiparsky, Paul. 2000. Opacity and cyclicity. The Linguistic Review 17: 351-365. 
Kochetov, Alexei. 2016. Palatalization and glide strengthening as competing repair strategies: Evidence from Kirundi. Glossa 1: 1-31.

Kryński, Adam. 1903. Gramatyka jezyka polskiego, 3rd edn. Warszawa: Wydawnictwo Arct.

Laskowski, Roman. 1975. Studia nad morfonologiq współczesnego jezzka polskiego. Wrocław: Ossolineum.

Lightner, Theodore M. 1963. Preliminary remarks on the morphophonemic component of Polish. Quarterly Progress Report 71: 220-235.

Ładoń, Franciszek. 1920. Gramatyka jezyka polskiego według uchwał Akademii Krakowskiej z dnia 9 lutego 1918 roku. Chicago: Polish Publishing Co.

Łubowicz, Anna. 2002. Derived environment effects in optimality theory. Lingua 112: 243-280.

Małecki, Antoni. 1863. Gramatyka jezyka polskiego większa. Lwów: Drukarnia Winiarza

McCarthy, John J. 1999. Sympathy and phonological opacity. Phonology 16: 331-399.

McCarthy, John J. 2003. Comparative markedness. Theoretical Linguistics 29: 1-51.

McCarthy, John J. 2007. Hidden generalizations: Phonological opacity in optimality theory. London: Equinox Publishing.

McCarthy, John J., and Alan Prince. 1995. Faithfulness and reduplicative identity. In University of Massachusetts occasional papers in linguistics 18, eds. Jill N. Beckman, Laura W. Dickey, and Suzanne Urbanczyk, 249-384. Amherst: GLSA.

Muczkowski, Józef. 1849. Gramatyka jezzyka polskiego. Kraków: Drukarnia Uniwersytecka.

Ohala, John. J. 1978. Southern Bantu vs. the world: The case of palatalization of labials. Berkeley Linguistic Society (BLS) 4: 370-386.

Pater, Joe. 2008. Morpheme-specific phonology: Constraint indexation and inconsistency resolution. In Phonological argumentation: Essays on evidence and motivation, ed. Steve Parker, 123-154. London: Equinox.

Pullum, Geoffrey. 1976. The Duke-of-York gambit. Journal of Linguistics 12: 83-102.

Prince, Alan, and Paul Smolensky. 2004. Optimality theory: Constraint interaction in generative grammar. Oxford: Blackwell.

Rubach, Jerzy. 1984. Cyclic and Lexical Phonology: The structure of Polish. Dordrecht: Foris Publications.

Rubach, Jerzy. 1986. Abstract vowels in three-dimensional phonology: The yers. The Linguistic Review 5: 247-280.

Rubach, Jerzy. 1997. Extrasyllabic consonants in Polish: Derivational Optimality Theory. In Derivations and constraints in phonology, ed. Iggy Roca, 551-581. Oxford: Oxford University Press.

Rubach, Jerzy. 2000a. Backness switch in Russian. Phonology 17: 39-64.

Rubach, Jerzy. 2000b. Glide and glottal stop insertion in Slavic languages: A DOT analysis. Linguistic Inquiry 31: 271-317.

Rubach, Jerzy. 2003. Polish palatalization in Derivational Optimality Theory. Lingua 113: 197-237.

Rubach, Jerzy. 2007. Feature geometry from the perspective of Polish, Russian and Ukrainian. Linguistic Inquiry 38: 85-138.

Rubach, Jerzy. 2011. Syllabic repairs in Macedonian. Lingua 121: 237-268.

Rubach, Jerzy. 2013. Exceptional segments in Polish. Natural Language and Lingvistic Theory 31: 11391162.

Rubach, Jerzy. 2016. Polish yers: Representation and analysis. Journal of Linguistics 52: 421-466.

Rubach, Jerzy. 2017. Derivational meanders of high vowel palatalization. Lingua 199: 1-26.

Rydzewski, Paweł. 2017. Unwarranted exceptionality: The case of Polish y. Lingua 189-190: 75-95.

Sagey, Elizabeth. 1986. The representation of features and relations in non-linear phonology. PhD diss., MIT.

Shevelov, George. 1979. A historial phonology of the Ukrainian language. Heidelberg: Winter.

Siegel, Dorothy. 1974. Topics in English morphology. PhD diss., MIT.

Sławski, Franciszek. 1952. Słownik etymologiczny. Kraków: Towarzystwo Miłośników Języka Polskiego.

Spencer, Andrew. 1986. A non-linear analysis of vowel-zero alternations in Polish. Journal of Linguistics 22: 249-280.

Steele, Richard D. 1973. The segmental phonology of Contemporary Standard Polish. PhD diss., Harvard University.

Stieber, Zdzisław. 1973. A historical phonology of the Polish language. Heidelberg: Carl Winter.

Wierzchowska, Bożena. 1963. Budowa akustyczna a artykulacyjna dźwięków mowy. Biuletyn Polskiego Towarzystwa Jezykoznawczego 22: 3-23.

Wierzchowska, Bożena. 1971. Wymowa polska. Warszawa: Państwowe Zakłady Wydawnictw Szkolnych. 
Wolf, Matthew A. 2008. Optimal interleaving: Serial phonology-morphology interaction in a constraintbased model. PhD diss., University of Massachusetts, Amherst.

Żygis, Marzena, and Silke Hamann. 2003. Perceptual and acoustic cues of Polish coronal fricatives. In International Congress of Phonetic Sciences (ICPhS) 15, eds. Maria-Josep Solé, Daniel Recasens and Joaquin Romero, 395-398. 